\title{
THE EFFECT OF DIFFERENT WELL WATER QUALITY AND IRRIGATION METHODS ON SOME CHEMICAL PROPERTIES AND SALINITY DISTRIBUTION OF SOIL IN ARID AREAS: A CASE STUDY OF ISMAILIA GOVERNORATE
}

\author{
W. E. Ahmed, K. S. El-Hedek and M. Abd-EladI \\ Soils, Water and Environment Research Institute (Agric. Res Center) Giza, Egypt.
}

Received: Sep. 27,2018

Accepted: Oct. 31,2018

\begin{abstract}
The increasing demand for irrigation water to secure food for growing populations with limited water supply suggests re-thinking the use of non-conventional water resources. The study was conducted to monitor the salinity distribution in soil under different well water quality and irrigation methods in specific sites of Ismailia Governorate region. Water and soil samples were collected from hundred randomly selected sites. Both soil and water samples were analyzed for chemical characteristic which included salinity, cations, anions and SAR. The findings indicated that the mean soil $\mathrm{pH}$ was 7.35 while the mean EC value was $3.73 \mathrm{dS} / \mathrm{m}$. The mean cations in the water samples were $7.43,5.98$, 0.17 , and $23.33 \mathrm{meq} / \mathrm{l}$ for $\mathrm{Ca}^{2+}, \mathrm{Mg}^{2+}, \mathrm{K}^{+}$, and $\mathrm{Na}^{+}$, respectively and the a mean value of Sodium Adsorption Ratio (SAR) was 9.11. The mean bicarbonates concentration detected in the irrigation water was 4.43 meq/l, while the mean chloride and sulphate were 29.95 and 2.49meq/l, respectively. The mean values of EC of soil were 3.94, 5.98 and 4.56 for drip, sprinkler and surface irrigation methods in depth $0-20 \mathrm{~cm}$, respectively. While, in soil depth $20-40 \mathrm{~cm}$ the mean values of EC were $6.78,4.94$ and 2.99 for drip, sprinkler and surface irrigation methods, respectively. The spatial distribution of soil salinity in the soil horizons were found to be higher at shallow depths of $0-20 \mathrm{~cm}$ and decreasing gradually up to a depth of $20-40 \mathrm{~cm}$. This trend is clear with surface and sprinkler irrigation method. In drip irrigated method, the salinity distribution showed a different pattern from that observed in surface and sprinkler irrigation. Salinity was the lowest in the surface layer $(0-20 \mathrm{~cm})$, and increased gradually with soil depth (20-40 cm). Salt concentration factor (SCF) of Ismailia soil under studies ranged between0.14 to 6.33. The results showed that SCF varies according to water and soil quality and irrigation methods.EC of soil was positively and significantly correlated with $\mathrm{Ca}^{2+}, \mathrm{Mg}^{2+}, \mathrm{Na}^{+}, \mathrm{K}^{+}, \mathrm{Cl}, \mathrm{HCO}_{3}{ }_{3}$ but positively and not significantly correlated with $\mathrm{pH}$ and $\mathrm{SO}^{2-}{ }_{4}$.The general trend showed that soil salinity increased with an increase in water salinity. Correlation coefficient $(r)$ between EC of irrigation water and EC of soil was $0.550^{* *}$.
\end{abstract}

Key words: Salinity, irrigation methods, Salt concentration factor, Ismailia Governorate.

\section{INTRODUCTION}

The continuous increase in the earth's population requires increasing quantities of water for domestic, industrial and agricultural needs. The progressive requirement for more water to irrigate crops for food when water resources are limited has led to reuse and recycling of the available water in agriculture (Ragab,
2005). In many regions of the world, drainage water is already used successfully for irrigation even when the water is saline (Grattan et al. 1994). Irrigation with saline water has become necessary not only in parts of the world with limited supplies of good quality water but also in areas affected by shallow 
ground water where the main purpose is to reduce the depth of the water table.

Different studies were done in relation to the influence of the irrigation with different qualities on the soil salinity and some physical specifications. Having used saline water for irrigation Zartman and Gicharu, (1984) indicated that the soil salinity process was often slow and depending on the water salinity which may be hidden for years after irrigation. Sajadi et al. (2012) assessed the effect of the irrigation water quality on the soil; their results indicated that the soil chemical properties were influenced more by the irrigation water qualities than the physical and fertilization parameters. Gretan et al. (1996) studies the waters with high electric conductivity and concluded that if their conductivity was more than 3 (dSI $\mathrm{m}$ ), they would be highly limited in view of irrigation; of course, it is possible to use the waters with high salinity according to the conditions special to the product, soil properties, irrigation methods and climatic situation. Moran et al. (2001) concluded that the irrigation with inappropriate water, depending on the quality and rate of the consumed water and irrigation system, has different effects on the soil physical and chemical properties. The tests conducted on the soils irrigated with saline water with high percent of sodium indicated that if the salinity increased, the sodium and calcium concentration would increase in the soil saturation extract and the soil electric conductivity would decrease. In a study a great space of a region irrigated with saline water and the results indicated that high amounts of salinity in the irrigation water has considerable effect on the soil properties such as its salinity and the latter decreases the product operation (Perez et al. 2003).

Drip irrigation method is not affected by high wind velocity as it applies water directly to the root zone of plants
(Sharma, 2001). Its major advantages as compared to other methods include: higher crop yields, saving in water, increased fertilizer use efficiency, reduced energy consumption, tolerance to windy atmospheric conditions, reduced labor cost, improved disease and pest control, feasible for undulating sloppy lands, suitability on problem soils and improved tolerance to salinity (Michael, 2008). In a study established by Yildirim and Korukcu, (2000) reported that drip irrigation generally achieves better crop yield and balanced soil moisture in the active root zone with minimum water losses. On the average, drip irrigation saves about 70 to $80 \%$ water as compared to conventional flood irrigation methods (Camp, et al., 2001). Furrow irrigation is said to be $30 \%$ in water use efficiency as compared to other conventional methods, Worldwide furrow irrigation is being adopted at about 90 percent of lands, reason behind is it's less need of energy. The water is being conserved in furrow irrigation method, as the water is applied to the root zones which are refilled at required depth (Tiercelin and Vidal, 2006). There are some disadvantages inherent with this technology (drip irrigation) such as; emitter clogging, which may be removed by the use of good quality filtration system and high material and installation cost. In past many studies have been conducted on drip irrigation method, even this farmers community prefer to adopt traditional flood irrigation methods. The mean target of this work is evaluating salinity status of Ismailia Governorate soils under irrigation with different quality of wells water and different irrigation methods.

\section{MATERIALS AND METHODS \\ Study area:}

This study was carried out in Ismailia Governorate located between the 
latitudes of $30^{\circ} 35^{\prime} 59.99^{\prime \prime} \mathrm{N}$ and the longitudes of $32^{\circ} 16^{\prime} 60.00^{\prime \prime} \mathrm{E}$. The climate of Ismailia has the arid climate of the interior desert with a high diurnal range in temperature. The maximum monthly average for temperature is $35.1 \mathrm{C}^{\circ}$ in July, August. 19.9 in January. During night, the temperature decreases where the minimum average limit is $7.1 C^{\circ}$ in January and $20.6 \mathrm{C}^{\circ}$ in August. The average annual rainfall for the area is about $50 \mathrm{~mm}$. The area receives approximately $60 \%$ of the total rainfall in the months of November, December, January and February. The rain is usually falling in very heavy showers, which last for a very short period.

\section{Water samples:}

One hundred water samples were collected from 100 wells which present different districts of Ismailia Governorate. Water samples for determining the water quality in general and other elements. Some data about location, irrigation method and cultivated plant were reported in Table (1). The following chemical determinations were conducted for the Water samples: Electrical conductivity (EC, dS/m), pH, sodium and potassium, calcium and magnesium. Soluble anions (meq/l): Carbonate and Bicarbonate, Chloride, Sulphate. Chapman and Pratt (1961). Boron (mg/l) by colorimetric determination using spectrophotometer.

\section{Soil samples;}

The soil samples were taken at two depths $(0-20$ and $20-40 \mathrm{~cm})$ from each area. Total number of the soil samples is200 sample to present 100 profiles. The collected soil samples were air dried, finely ground to pass through a $2 \mathrm{~mm}$ sieve and stored for analysis in plastic bags. The following chemical determinations were conducted for the soil samples; electrical conductivity (EC), soluble cations and soluble anions (meq/l) were determined in soil saturation extract as mentioned above in water samples analysis. pH was determined in soil suspension 1:2.5 soil water ratio. The data of the soil in the region has been collected to observe the changes in soil salinity and alkalinity for a given soil depth.

The salt concentration factor was measured by following Miyamoto and Chacon, 2006): Where: SCF = ECe/ECw

SCF $=$ Salt concentration factor.

$\mathrm{ECe}=$ Electrical conductivity of soil water paste extract.

$\mathrm{ECw}=$ Irrigation water conductivity.

\section{RESULTS AND DISCUSSION}

The results obtained from water and soil analysis such as soil $\mathrm{pH}$, electrical conductivity (EC), cations, anions and Sodium Adsorption Ratio (SAR) are shown in Table (2). The water quality parameters are also presented and compared with water quality standards. In addition, comparison between the results was also done.

\section{Chemical properties of well water pH Values:}

The $\mathrm{pH}$ values varied between 6.89 to 7.88 with a mean value of 7.35 . All the water $\mathrm{pH}$ values are slightly alkaline expect 5 samples having $\mathrm{pH}$ values slightly less than 7. (Table, 2). Ayers and West coast (1976) reported that, pH between (6.5) to (8.4) is considered very suitable for irrigation water. Generally, $\mathrm{pH}$ values for normal irrigation water should be between 6.00 and 7.00 , while values above 7.00 are considered as of increasing hazard (Danko 1997). As it has a marked influence on other characteristics or reactions in the soil and water, as well as the way plants perform. 
W. E. Ahmed, et al.,

Table (1): Locality of the wells, irrigation method and cultivated crop.

\begin{tabular}{|c|c|c|c|c|c|c|c|}
\hline No & Locality & $\begin{array}{c}\text { irrigation } \\
\text { method }\end{array}$ & $\begin{array}{c}\text { Cultivated } \\
\text { plant }\end{array}$ & No & Locality & $\begin{array}{c}\text { irrigation } \\
\text { method }\end{array}$ & $\begin{array}{c}\text { Cultivated } \\
\text { plant }\end{array}$ \\
\hline 1 & \multirow{10}{*}{$\begin{array}{l}\text { Kantra } \\
\text { Gharb }\end{array}$} & Surface & Wheat & 51 & \multirow[t]{5}{*}{ Faid } & Surface & Clover. \\
\hline 2 & & Drip & Maize & 52 & & Drip & Pears \\
\hline 3 & & Surface & Olive & 53 & & Drip & Olive \\
\hline 4 & & Drip & Alfalfa & 54 & & Drip & Spear \\
\hline 5 & & Drip & Alfalfa & 55 & & Drip & Olive \\
\hline 6 & & Drip & Onion & 56 & \multirow{39}{*}{$\begin{array}{c}\text { Kantra } \\
\text { Gharb }\end{array}$} & Surface & Onion \\
\hline 7 & & Surface & Clover & 57 & & Drip & Olive \\
\hline 8 & & Drip & Cantaloupe & 58 & & Drip & Olive \\
\hline 9 & & Surface & Clover & 59 & & Drip & Olive \\
\hline 10 & & Surface & Olive & 60 & & Drip & Olive \\
\hline 11 & \multirow[t]{5}{*}{ El-Manaif } & Sprinklerr & Wheat & 61 & & Surface & Bean \\
\hline 12 & & Drip & Botatos & 62 & & Drip & Paper \\
\hline 13 & & Drip & Olive & 63 & & Surface & Wheat \\
\hline 14 & & Drip & Alfalfa & 64 & & Sprinklerr & Clover \\
\hline 15 & & Surface & Olive & 65 & & Drip & Olive \\
\hline 16 & \multirow{8}{*}{$\begin{array}{l}\text { Kantra } \\
\text { Shark }\end{array}$} & Drip & Olive & 66 & & Drip & Olive \\
\hline 17 & & Drip & Olive & 67 & & Sprinklerr & Clover \\
\hline 18 & & Drip & Alfalfa & 68 & & Drip & Olive \\
\hline 19 & & Drip & Tomato & 69 & & Drip & Olive \\
\hline 20 & & Surface & Wheat & 70 & & Drip & Olive \\
\hline 21 & & Drip & Olive & 71 & & Drip & Paper \\
\hline 22 & & Sprinklerr & Wheat & 72 & & Drip & Olive \\
\hline 23 & & Drip & Olive & 73 & & Surface & Olive \\
\hline 24 & \multirow[t]{7}{*}{ El-Manaiff } & Drip & Olive & 74 & & Drip & Olive \\
\hline 25 & & Drip & Olive & 75 & & Drip & Olive \\
\hline 26 & & Drip & Bean & 76 & & Drip & Tomato \\
\hline 27 & & Drip & Onion & 77 & & Drip & Onion \\
\hline 28 & & Sprinklerr & Wheat & 78 & & Drip & Olive \\
\hline 29 & & Drip & Olive & 79 & & Sprinklerr & Wheat \\
\hline 30 & & Drip & Alfalfa & 80 & & Drip & Olive \\
\hline 31 & \multirow[t]{20}{*}{ Faid } & Drip & Onion & 81 & & Drip & Alfalfa \\
\hline 32 & & Surface & Wheat & 82 & & Drip & Olive \\
\hline 33 & & Drip & Cantaloupe & 83 & & Drip & Olive \\
\hline 34 & & Drip & Cantaloupe & 84 & & Drip & Tomato \\
\hline 35 & & & Squash & 85 & & Drip & Alfalfa \\
\hline 36 & & Drip & Mango & 86 & & Drip & Olive \\
\hline 37 & & Drip & Onion & 87 & & Drip & Paper \\
\hline 38 & & Drip & Olive & 88 & & Drip & Olive \\
\hline 39 & & Drip & Guava & 89 & & Drip & Olive \\
\hline 40 & & Surface & Olive & 90 & & Drip & Paper \\
\hline 41 & & Drip & Onion. & 91 & & Surface & Wheat \\
\hline 42 & & Surface & Onion & 92 & & Surface & Olive \\
\hline 43 & & Drip & Olive & 93 & & Drip & Paper \\
\hline 44 & & Surface & Clover & 94 & & Drip & Olive \\
\hline 45 & & Surface & Clover. & 95 & \multirow[t]{6}{*}{ Faid } & Drip & Olive \\
\hline 46 & & Drip & Alfalfa & 96 & & Drip & Alfalfa \\
\hline 47 & & Surface & Wheat & 97 & & Sprinklerr & Clover \\
\hline 48 & & Drip & Olive & 98 & & Drip & Olive \\
\hline 49 & & Drip & Olive & 99 & & Drip & Olive \\
\hline 50 & & Drip & Olive & 100 & & Drip & Olive \\
\hline
\end{tabular}


Table (2): Chemical analysis of the water wells samples of Ismailia Governorate

\begin{tabular}{|c|c|c|c|c|c|c|c|c|c|c|c|c|}
\hline \multirow{2}{*}{ No. } & \multirow[t]{2}{*}{ H } & \multirow{2}{*}{$\begin{array}{c}\mathrm{EC} \\
\mathrm{dS} / \mathrm{m}\end{array}$} & $\mathrm{a}^{++}$ & $\mathrm{Mg}^{++}$ & $\mathrm{Na}^{+}$ & $\mathrm{K}^{+}$ & $\mathrm{CO}_{3}=$ & $\mathrm{CO}_{3}$ & $\mathrm{Cl}^{-}$ & SO4 $=$ & \multirow{2}{*}{$\begin{array}{c}\mathrm{B} \\
\mathrm{mg} / \mathrm{l}\end{array}$} & \multirow{2}{*}{ SAR } \\
\hline & & & \multicolumn{8}{|c|}{ meq/l } & & \\
\hline 1 & 7.38 & 4.31 & 6.70 & 6.00 & 30.20 & 0.16 & 0.00 & 5.00 & 37.60 & 0.46 & 1.09 & 11.98 \\
\hline 2 & 7.24 & 5.16 & 7.00 & 5.00 & 38.50 & 0.68 & 0.00 & 5.60 & 45.30 & 0.28 & 1.32 & 15.72 \\
\hline 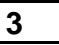 & 7.22 & 5.27 & 7.60 & 5.00 & 39.50 & 0.17 & 0.00 & 3.20 & 48.80 & 0.27 & 1.01 & 15.74 \\
\hline 4 & 7.33 & 3.38 & 4.70 & 3.20 & 25.40 & 0.13 & 0.00 & 4.80 & 28.30 & 0.33 & 1.63 & 12.78 \\
\hline 5 & 13 & 4.69 & 9.00 & 4.30 & 32.60 & 0.16 & 0.00 & 4.60 & 40.90 & 0.56 & 1.69 & 12.64 \\
\hline 6 & .53 & 4.68 & 7.30 & 4.70 & 34.00 & 0.24 & 0.00 & 3.80 & 41.90 & 0.54 & 1.16 & 13.88 \\
\hline 7 & 7.62 & 4.13 & 7.00 & 3.70 & 29.90 & 0.14 & 0.00 & 4.30 & 35.60 & 0.84 & 1.70 & 12.93 \\
\hline 8 & 7.32 & 3.90 & 4.30 & 2.00 & 32.60 & 0.09 & 0.00 & 4.30 & 33.90 & 0.79 & 0.83 & 18.37 \\
\hline 9 & 7.42 & 6.79 & 11.30 & 7.00 & 49.20 & 0.21 & 0.00 & 3.80 & 63.20 & 0.71 & 1.01 & 16.27 \\
\hline 10 & 7.53 & 5.23 & 6.30 & 7.30 & 37.20 & 1.13 & 0.00 & 4.30 & 44.60 & 3.03 & 1.10 & 14.27 \\
\hline 11 & 7.76 & 2.44 & 2.30 & 5.00 & 17.30 & 0.09 & 0.00 & 7.00 & 17.60 & 0.09 & 1.47 & 9.06 \\
\hline 12 & 7.16 & 4.45 & 9.60 & 5.70 & 29.00 & 0.14 & 0.00 & 5.30 & 38.30 & 0.84 & 0.94 & 0.48 \\
\hline 13 & 7.55 & 3.84 & 6.30 & 5.00 & 27.50 & 0.13 & 0.00 & 7.30 & 31.30 & 0.33 & 1.09 & 11.57 \\
\hline 14 & 7.30 & 3.53 & 6.70 & 5.30 & 22.50 & 0.13 & 0.00 & 7.00 & 27.60 & 0.03 & 1.10 & 9.19 \\
\hline 15 & 7.21 & 6.64 & 9.70 & 14.30 & 39.20 & 0.19 & 0.0 & 3.30 & 59.90 & 0.19 & 1.16 & 11.32 \\
\hline 16 & 56 & 5.19 & 7.00 & 4.30 & 40.20 & 0.12 & 0.0 & 4.00 & 44.60 & 3.02 & 0.90 & 6.91 \\
\hline 17 & 7.29 & 3.66 & 5.60 & 5.70 & 24.30 & 0.09 & 0.0 & 4.00 & 27.60 & 4.09 & 0.90 & 0.22 \\
\hline 18 & 7.15 & 2.60 & 4.70 & 4.60 & 16.50 & 0.09 & 0.00 & 4.00 & 17.60 & 4.29 & 1.09 & 7.65 \\
\hline 19 & 7.23 & 3.95 & 7.00 & 4.70 & 27.00 & 0.09 & 0.00 & 4.60 & 30.60 & 3.59 & 1.47 & 11.16 \\
\hline 20 & 7.60 & 2.31 & 4.30 & 4.30 & 14.30 & 0.11 & 0.00 & 4.70 & 18.00 & 0.31 & 1.44 & 6.90 \\
\hline 21 & 7.22 & 13.83 & 42.30 & 32.60 & 62.90 & 0.29 & 0.0 & 2.00 & 132.00 & 3.89 & 1.64 & 10.28 \\
\hline 22 & 7.15 & 6.98 & 16.30 & 15.30 & 38.30 & 0.13 & 0.0 & 2.30 & 65.90 & 1.53 & 2.32 & 9.64 \\
\hline 23 & 7.15 & 6.87 & 13.30 & 15.30 & 38.00 & 0.49 & 0.0 & 3.30 & 22.60 & 1.19 & 0.90 & 10.05 \\
\hline 24 & 7.71 & 1.57 & 3.70 & 3.30 & 7.90 & 0.12 & 0.00 & 3.00 & 10.00 & 2.20 & 2.32 & 4.22 \\
\hline 25 & 7.46 & 3.15 & 5.40 & 4.80 & 20.00 & 0.11 & 0.00 & 3.00 & 23.00 & 4.31 & 2.32 & 8.86 \\
\hline 26 & 7.38 & 1.34 & 3.60 & 3.00 & 6.10 & 0.10 & 0.00 & 2.60 & 8.80 & 1.40 & 0.90 & 3.36 \\
\hline 27 & 7.2 & 1.3 & 3.60 & 3 & 90 & 0.10 & 0.1 & 2.20 & 8.00 & 2.40 & 1.00 & 3.25 \\
\hline 28 & 7.75 & 2.89 & 7.0 & 5.21 & 15.60 & 0.10 & 0.0 & 4.20 & 21.00 & 2.70 & 0.86 & 6.32 \\
\hline 29 & 7.35 & 4.12 & 9.4 & 6.80 & 24.60 & 0.19 & 0.0 & 4.20 & 4.80 & 1.99 & 1.10 & 8.64 \\
\hline 30 & 7.46 & 2.18 & 4.30 & 3.70 & 13.50 & 0.13 & 0.00 & 3.00 & 16.40 & 2.23 & 1.15 & 6.75 \\
\hline 31 & 7.40 & 3.35 & 7.40 & 5.80 & 19.50 & 0.16 & 0.00 & 4.60 & 25.80 & 2.46 & 1.63 & 7.59 \\
\hline 32 & 7.3 & 3. & & 5 & 21.30 & 0. & 0. & 4.40 & & 3.03 & 1.02 & 7.73 \\
\hline 33 & 7.13 & 2.50 & 6.5 & 4.6 & 13.70 & 0.1 & 0.1 & 4.00 & 16.80 & 4.16 & 1.32 & 5.82 \\
\hline 34 & 7.34 & 3.18 & 7.6 & 7.90 & 14.60 & 0.35 & 0.0 & 3.60 & 23.80 & 3.05 & 0.90 & 5.24 \\
\hline 35 & 7.36 & 2.23 & 7.00 & 6.90 & 8.30 & 0.26 & 0.00 & 3.60 & 13.90 & 4.96 & 0.99 & 3.15 \\
\hline 36 & 7.20 & 1.60 & 5.60 & 5.60 & 4.20 & 0.22 & 0.00 & 3.90 & 8.20 & 3.52 & 1.01 & 1.77 \\
\hline 37 & 7.52 & 3.12 & 6.60 & 6.90 & 16.40 & 0.35 & 0.0 & 4.60 & 25.10 & 0.55 & 1.16 & 6.31 \\
\hline 38 & 727 & 4.26 & 70 & 290 & 11.50 & 0.33 & 0.0 & 4.60 & 33.30 & 4.03 & 1.69 & 2.96 \\
\hline 39 & 7.11 & 5.21 & 11.90 & 13.50 & 25.70 & 0.28 & 0.0 & 4.60 & 46.00 & 0.78 & 1.10 & 7.21 \\
\hline 40 & 7.51 & 2.78 & 3.30 & 4.30 & 19.90 & 0.13 & 0.00 & 3.60 & 20.50 & 3.53 & 1.15 & 10.21 \\
\hline 41 & 7.41 & 3.62 & 4.90 & 5.60 & 24.70 & 0.21 & 0.00 & 4.30 & 28.00 & 3.11 & 0.90 & 10.78 \\
\hline 42 & 7.36 & 3.34 & 5.60 & 5.60 & 21.40 & 0.26 & 0.00 & 3.60 & 26.00 & 3.26 & 1.69 & 9.04 \\
\hline 43 & 7.35 & 3.21 & 4.9 & 3.9 & 22.80 & 0.15 & 0.0 & 3.90 & 24.10 & 3.75 & 0.86 & 10.87 \\
\hline 44 & 7.1 & $2.4 \varepsilon$ & 5.0 & $4.2 C$ & 15.30 & 0.1 & 0.0 & 4.00 & 18.40 & 2.21 & 1.37 & 7.13 \\
\hline 45 & 7.79 & 2.12 & 4.2 & 3.60 & 12.90 & 0.34 & 0.0 & 3.40 & 14.00 & 3.64 & 0.94 & 6.53 \\
\hline 46 & 7.4 & 2.76 & 48 & 4.00 & 18.70 & 0.07 & 0.00 & 3.80 & 19.00 & 4.77 & 0.73 & 8.91 \\
\hline 47 & 7.16 & 3.65 & 6.60 & 4.00 & 24.90 & 0.14 & 0.00 & 4.00 & 28.00 & 3.64 & 1.32 & 10.82 \\
\hline 48 & 7.55 & 2.16 & 4.80 & 3.60 & 12.90 & 0.11 & 0.00 & 3.00 & 14.00 & 4.41 & 0.89 & 6.29 \\
\hline 49 & 7.76 & 2.41 & 5.80 & 5.00 & 12.80 & 0.12 & 0.0 & 3.40 & 14.20 & 6.12 & 0.59 & 5.51 \\
\hline 50 & 7.56 & 2.89 & 6.40 & 5.00 & 17.40 & 0.12 & 0.00 & 4.00 & 19.00 & 5.92 & 1.79 & 7.29 \\
\hline
\end{tabular}


W. E. Ahmed, et al.,

Table (2): Cont.

\begin{tabular}{|c|c|c|c|c|c|c|c|c|c|c|c|c|}
\hline \multirow{2}{*}{ No. } & \multirow{2}{*}{ pH } & \multirow{2}{*}{$\begin{array}{c}\mathrm{EC} \\
\mathrm{dS} / \mathrm{m}\end{array}$} & $\overline{a++}$ & $\mathrm{g}++$ & $\mathrm{Na}+$ & $\mathrm{K}+$ & $\mathrm{CO} 3=$ & $\mathrm{HCO}$ & $\overline{\mathrm{Cl}-}$ & SO4= & \multirow{2}{*}{$\begin{array}{c}\mathrm{B} \\
\mathrm{mg} / \mathrm{l}\end{array}$} & \multirow{2}{*}{ SAR } \\
\hline & & & \multicolumn{8}{|c|}{ meq/l } & & \\
\hline 51 & 7.44 & 2.70 & 6.20 & 5.80 & 15.00 & 0.11 & 0.00 & 4.00 & 17.40 & 5.71 & 1.02 & 6.12 \\
\hline 52 & 7.56 & 2.29 & 6.40 & 4.80 & 10.70 & 0.07 & 0.00 & 3.80 & 11.20 & 6.97 & 0.67 & 4.52 \\
\hline 53 & 7.32 & 4.83 & 10.60 & 6.60 & 29.60 & 0.16 & 0.00 & 3.80 & 38.60 & 4.56 & 1.24 & 10.09 \\
\hline 54 & 7.36 & 4.47 & 10.00 & 7.60 & 26.30 & 0.16 & 0.00 & 5.20 & 38.40 & 0.46 & 1.53 & 8.87 \\
\hline 55 & 7.41 & 2.82 & 6.60 & 5.00 & 16.70 & 0.09 & 0.00 & 4.00 & 19.20 & 5.19 & 0.64 & 6.93 \\
\hline 56 & 7.25 & 2.61 & 5.50 & 4.40 & 16.10 & 0.08 & 0.00 & 4.00 & 17.80 & $\begin{array}{l}4.28 \\
\end{array}$ & 1.07 & 7.24 \\
\hline 57 & 7.33 & 3.86 & 6.60 & 4.60 & 25.70 & 0.14 & 0.00 & 4.20 & 29.20 & 3.64 & 1.03 & 10.86 \\
\hline 58 & 7.21 & 2.92 & 5.80 & 40 & 19.60 & 0.11 & 0.00 & 4.00 & 22.40 & 3.51 & 1.31 & 8.68 \\
\hline 59 & 6.98 & 3.11 & 6.40 & 20 & 19.30 & 0.11 & 0.00 & 3.80 & 23.60 & 3.61 & 0.92 & 8.01 \\
\hline 60 & 7.46 & 2.88 & 6.40 & .40 & 18.90 & 0.09 & 0.00 & 4.00 & 21.00 & 3.79 & 1.01 & 8.54 \\
\hline 61 & 7.68 & 2.09 & 5.00 & 4.60 & 10.70 & 0.10 & 0.00 & 4.00 & 12.30 & 4.10 & 0.92 & 4.88 \\
\hline 62 & 7.21 & 3.68 & 5.80 & 4.60 & 25.50 & 0.14 & 0.00 & 3.40 & 28.00 & 4.64 & 0.64 & 11.18 \\
\hline 63 & 7.47 & 2.09 & 4.90 & 4.60 & 10.80 & 0.08 & 0.00 & 4.00 & 12.00 & $\begin{array}{l}4.38 \\
\end{array}$ & 1.71 & 4.96 \\
\hline 64 & 7.47 & 2.01 & 4.70 & 4.20 & 10.50 & 0.10 & 0.00 & 3.60 & 11.30 & 4.60 & 1.24 & 4.98 \\
\hline 65 & 7.25 & 3.20 & 6.20 & 40 & 22.30 & 0.16 & 0.00 & 4.00 & 26.00 & 3.06 & 1.64 & 9.69 \\
\hline 66 & 7.38 & 2.87 & 6.40 & 4.80 & 15.70 & 0.11 & 0.00 & 3.80 & 19.00 & 4.21 & 1.37 & 6.63 \\
\hline 67 & 7.35 & 3.50 & 6.30 & 4.20 & 23.70 & 0.14 & 0.00 & 3.40 & 27.80 & 3.14 & 1.44 & 10.34 \\
\hline 68 & 7.64 & 2.37 & 5.00 & 4.20 & 14.30 & 0.11 & 0.00 & 3.50 & 16.00 & 4.11 & 1.01 & 6.67 \\
\hline 69 & 7.22 & 6.90 & 14.40 & 0 & 45.90 & 0.1 & 0.00 & 4.00 & 61.00 & 4.06 & 1.44 & 13.54 \\
\hline 70 & 7.36 & 4.83 & 8.20 & .40 & 27.60 & 0.16 & 0.00 & 5.00 & 37.20 & 0.16 & 1.70 & 10.22 \\
\hline 71 & 7.53 & 2.38 & 4.00 & 5.80 & 15.90 & 0.16 & 0.00 & 3.20 & 22.40 & 0.26 & 1.71 & 7.18 \\
\hline 72 & 7.33 & 4.62 & 10.00 & 6.60 & 29.10 & 0.16 & 0.00 & 3.40 & 38.00 & 4.46 & 1.09 & 10.10 \\
\hline 73 & 7.46 & 7.12 & 15.40 & 8.20 & 46.50 & 0.16 & 0.00 & 6.00 & 60.80 & 3.46 & 1.16 & 13.54 \\
\hline 74 & 7.51 & 2.9 & 740 & 6.00 & 16.10 & 0.1 & 0.0 & 4.20 & 22.40 & 3.0 & 0.83 & 6.22 \\
\hline 75 & 7.41 & 7.51 & 14.00 & .00 & 51.70 & 0.1 & 0.0 & 5.60 & 66.80 & 2.46 & 1.01 & 15.25 \\
\hline 76 & 7.24 & 3.38 & 7.90 & 30 & 18.90 & 0.1 & 0.00 & 4.00 & 26.00 & 3.23 & 1.10 & 7.09 \\
\hline 77 & 7.33 & 3.15 & 6.20 & 10 & 18.30 & 0.1 & 0.00 & 3.70 & 23.90 & 3.16 & 0.54 & 7.38 \\
\hline 78 & 7.23 & 3.17 & 4.30 & 5.70 & 21.20 & 0.17 & 0.00 & 3.60 & 23.30 & 4.47 & 1.01 & 9.48 \\
\hline 79 & 6.94 & $\begin{array}{ll}7.37 \\
\end{array}$ & 17.90 & 10.00 & 44.80 & 0.16 & 0.00 & 4.90 & 64.60 & 3.36 & 1.06 & 11.99 \\
\hline 80 & 7. & 6.5 & 10.70 & 0 & 44.30 & 0.2 & 0. & 4.90 & 58.00 & 2.32 & 1.63 & 3.77 \\
\hline 81 & 7.23 & 3.37 & 5.70 & 3.70 & 23.90 & 0.1 & 0.0 & 4.30 & 26.00 & 3.17 & 0.90 & 11.02 \\
\hline 82 & 7.19 & 4.35 & 8.30 & 70 & 27.20 & 0.19 & 0.00 & 3.30 & 36.90 & 3.19 & 1.09 & 9.62 \\
\hline 83 & 6.89 & 3.89 & 8.70 & 6.30 & 23.00 & 0.22 & 0.00 & 4.90 & 31.90 & 1.42 & 0.94 & 8.40 \\
\hline 84 & 7.12 & 2.27 & 4.70 & 3.70 & 14.10 & 0.14 & 0.00 & 3.90 & 15.30 & 3.44 & 0.54 & 6.88 \\
\hline 85 & 7.06 & 5.94 & 13.30 & 9.00 & 36.80 & 0.0 & 0.00 & 5.00 & 53.00 & 1.19 & 1.79 & 11.02 \\
\hline 86 & 7.5 & 344 & 770 & 90 & 23.50 & 0.0 & 0 & 6.30 & 29.60 & 0 & 1.23 & 9.40 \\
\hline 87 & 7.8 & 3.1 & 6.00 & 5.30 & 18.90 & 0.1 & 0.00 & 6.70 & 22.30 & 1.33 & 0.64 & 7.95 \\
\hline 88 & 7.25 & 4.22 & 9.00 & 7.70 & 25.30 & 0.20 & 0.00 & 5.60 & 35.90 & 0.70 & 0.73 & 8.76 \\
\hline 89 & 6.97 & 2.48 & 5.70 & 4.00 & 14.50 & 0.13 & 0.00 & 6.30 & 18.00 & 0.03 & 1.01 & 6.58 \\
\hline 90 & 7.22 & 2.96 & 5.70 & 3.70 & 19.90 & 0.14 & 0.00 & 6.30 & 23.00 & 0.14 & 1.22 & 9.18 \\
\hline 91 & 7.8 & 2.84 & 4.00 & 6.70 & 17.50 & 0.1 & 0.0 & 6.90 & 21.30 & 0.14 & 1.23 & 7.57 \\
\hline 92 & 7.0 & 3.1 & 4.0 & 4.3 & 21.50 & 0.14 & 0.00 & 4.90 & 24.60 & 0.44 & 1.53 & 10.55 \\
\hline 93 & 7.52 & 276 & 40 & 10 & 19.50 & 0.14 & 0.0 & 6.30 & 20.30 & 0.44 & 0.90 & 10.14 \\
\hline 94 & 7.19 & 2.65 & 5.00 & 3.90 & 16.90 & 0.13 & 0.00 & 6.70 & 19.00 & 0.23 & 1.16 & 8.01 \\
\hline 95 & $\begin{array}{l}7.27 \\
\end{array}$ & 5.57 & 9.40 & 6.00 & 39.50 & 0.14 & 0.00 & 5.80 & 46.80 & 2.44 & 1.09 & 14.23 \\
\hline 96 & $\begin{array}{l}7.39 \\
\end{array}$ & 3.23 & 4.60 & 4.40 & 23.10 & 0.14 & 0.00 & 6.80 & 25.20 & 0.24 & 0.90 & 10.89 \\
\hline 97 & 7.02 & 3.89 & 6.40 & 5.40 & 26.30 & 0.13 & 0.0 & 7.40 & 29.80 & 1.03 & 1.70 & 10.83 \\
\hline 98 & 7.45 & 2.5 & 5.00 & 4.60 & 15.90 & 0.11 & 0.00 & 7.00 & 18.20 & 0.41 & 1.47 & 7.26 \\
\hline 99 & 7.70 & 2.3 & 5.00 & 3.40 & 14.80 & 0.1 & 0.0 & 7.00 & 16.30 & 0.01 & 1.08 & 7.22 \\
\hline 100 & 7.27 & 3.20 & 6.60 & 5.00 & 20.80 & 0.16 & 0.00 & 4.60 & 23.00 & 4.96 & 1.22 & 8.64 \\
\hline
\end{tabular}




\section{EC Values:}

The concentration of total salt content in irrigation waters is estimated in terms of $\mathrm{EC}_{\mathrm{w}}$ and it may be the most important parameter for assessing the suitability of irrigation waters, Ajayi et al., (1990). It gives an estimate of the total amounts of dissolved salts in the water and the total amount and kinds of salts determine the suitability of the water for irrigation use (Belan, 1985). The wells water EC ranged from 1.32 to 13.83 with mean value 3.73 $\mathrm{dS} / \mathrm{m}$. Generally, the suitability for irrigation water ranged from $<0.7$ to 2.0 $\mathrm{dS} / \mathrm{m}$. Comparing with $\mathrm{FAO} \mathrm{EC}_{\mathrm{w}}$ blow 3.0 was suitable limit for irrigation (FAO., 1985).

According to the classification of saline waters as shown in Table (3), It can be noticed that $4 \%$ of the water samples were slightly saline, $95 \%$ were moderately saline, while $1 \%$ highly saline

\section{Soluble $\mathrm{Na}$}

The amount of $\mathrm{Na}$ ions in the water predicts the sodicity danger of the water (Singah, 2000). The Na ions of wells water ranged from 4.20 to 62.90 with a mean value of $23.33 \mathrm{meq} / \mathrm{ll}$,. Sodium ions are important criteria for irrigation water quality because of its effect on soil permeability and water infiltration (Ajayi et al., 1990). Sodium also contributes directly to the total salinity of the water and may be toxic to sensitive crops such as fruit trees. Sodium ions cause deflocculating of particles and subsequent sealing of soil pores thereby preventing water passage into the soil. Sodic water causes excess $\mathrm{Na}$ to be adsorbed to exchange complex and in the process causes dispersion of aggregates and thereby blocking pores in the soil and preventing or reducing infiltration of applied water. Generally, values greater than $0.4 \mathrm{meq} / \mathrm{l}$ in terms of $\mathrm{Na}$ concentrations are regarded as posing increasing severity of sodicity especially in soils high in clay content (Davis and Dewest, 1966). The value recorded in a few well irrigation water may therefore be interpreted as posing severe risk factor of sodium toxicity to the soil. $\mathrm{Na}$ concentration below $900 \mathrm{mg} / \mathrm{lis}$ within the permissible limit for irrigation water. Based on the results and on the standards given by FAO, 1985 for using the water and for discharging them on land for irrigation (FAO, 1985).

Table (3). Classification of saline waters*

\begin{tabular}{|l|c|c|l|}
\hline \multicolumn{1}{|c|}{ Water class } & $\begin{array}{c}\text { Electrical } \\
\text { conductivity dS/m }\end{array}$ & $\begin{array}{c}\text { Salt concentration } \\
\mathrm{mg} / \mathrm{l}\end{array}$ & \multicolumn{1}{|c|}{ Type of water } \\
\hline Non-saline & $<0.7$ & $<500$ & $\begin{array}{l}\text { Drinking and irrigation } \\
\text { water }\end{array}$ \\
\hline Slightly saline & $0.7-2$ & $500-1500$ & Irrigation water \\
\hline $\begin{array}{l}\text { Moderately } \\
\text { saline }\end{array}$ & $2-10$ & $1500-7000$ & $\begin{array}{l}\text { Primary drainage water and } \\
\text { groundwater }\end{array}$ \\
\hline Highly saline & $10-25$ & $7000-15000$ & $\begin{array}{l}\text { Secondary drainage water } \\
\text { and groundwater }\end{array}$ \\
\hline $\begin{array}{l}\text { Very highly } \\
\text { saline }\end{array}$ & $25-45$ & $15000-35000$ & Very saline groundwater \\
\hline Brine & $>45$ & $>45000$ & Seawater \\
\hline
\end{tabular}

*FAO, 1992, The use of saline waters for crop production - FAO irrigation and drainage paper 48 


\section{Soluble $\mathrm{Ca}^{2+}$ and $\mathrm{Mg}^{2+}$ :}

The calcium in well water ranged from 2.30 to $42.30 \mathrm{meq} / \mathrm{l}$, with a mean value of $7.43 \mathrm{meq} / \mathrm{l}$. The normal range of $\mathrm{Ca}^{2+}$ in irrigation water should be between 0 $1.0 \mathrm{meq} / \mathrm{l}$. The magnesium in well water ranged from 2.00 to $32.60 \mathrm{meq} / \mathrm{l}$, with a mean value of $5.98 \mathrm{meq} / \mathrm{l}$, while the normal range of $\mathrm{Mg}^{2+}$ should be between $0-0.2$ meq/l (Christenson, et al., 1977). By these criteria the calcium content of irrigation water could be described as being above the safe limit. This also applies to the magnesium content which is above the recommended mean. The magnesium content of water is also considered as important qualitative criteria in determining the quality of water for irrigation because more magnesium in water will adversely affect crop yields, as the soils become more alkaline. Generally, calcium and magnesium maintain a state of equilibrium in most waters (Christenson, et al., 1977). The combined effect of these two ions is in their countering the negative effect of the sodium by lowering the SAR. According by FAO, 1985 standard limit for calcium and magnesium in Irrigation water were below400 and $60 \mathrm{mg} / \mathrm{l}$ ) for calcium and magnesium, respectively (FAO, 1985).

\section{Soluble potassium:}

The potassium in well water ranged from 0.07 to $1.13 \mathrm{meq} / \mathrm{l}$ with a mean value of 0.17 . The presence of potassium ions in excessive amounts does not constitute any risk and may even supplement crops' needs as only values exceeding 1.3 meq/l may be considered as posing any serious risk factor with irrigation water. The standard limit for irrigation water recorded $0.2 \mathrm{mg} / \mathrm{l}$ for potassium (FAO, 1985).

\section{Anions}

Soluble carbonate and bicarbonates:

The quality of the irrigation water in terms of anions is as shown in Table (2) . The bicarbonate in well water ranged from 2.00 to $7.40 \mathrm{meq} / \mathrm{l}$, with a mean value of $4.43 \mathrm{meq} / \mathrm{l}$. The normal safe ranking for carbonate $\left(\mathrm{CO}_{3}{ }^{2-}\right)$ and bicarbonates $\left(\mathrm{HCO}_{3}{ }^{-}\right)$are 0.03 and $0.16 \mathrm{meq} / \mathrm{l}$, respectively (Landon, 1991). By this criteria therefore, the irrigation water could be described as being at severe risk with regards bicarbonates. High carbonate and bicarbonate in water essentially increases the sodium hazard of the water to a level greater than that indicated by the SAR. High $\mathrm{HCO}_{3}{ }^{-}$tend to precipitate calcium carbonate $\left(\mathrm{CaCO}_{3}\right)$ and magnesium carbonate $\left(\mathrm{MgCO}_{3}\right)$, when the soil solution concentrates during soil drying. If the concentrations of calcium and magnesium in soil solution are reduced relative to sodium, the SAR of the soil solution tends to increase (Michael, 1985). High alkalinity indicates that the water will tend to increase the $\mathrm{pH}$ of the soil or growing media, possibly to a point that is detrimental to plant growth. Another aspect of alkalinity is its potential effect on sodium. Soil irrigated with alkaline water may, upon drying, cause an excess of available sodium. Several potential sodium problems as mentioned above could therefore result. Among the components of water alkalinity, bicarbonates are normally the most significant concern. The concentration of the $\mathrm{CO}_{3}{ }^{2-}$ in groundwater is generally lower than of the $\mathrm{HCO}_{3}{ }^{-}$ions (El-Aassy et al. 2015). High levels of bicarbonates can be directly toxic to some plant species. Bicarbonate levels above $3.3 \mathrm{cmol} / \mathrm{l}$ will cause lime (calcium and magnesium carbonate) to be deposited on soils and even on foliage especially when irrigated with overhead sprinklers. This may be undesirable for vegetable plants. Similar levels of bicarbonates may also cause lime deposits to form on roots, which can be especially damaging too many tree species (Adamu, 2013). 


\section{Solublechloride:}

The chloride in well water ranged from 8.00 to 132.0 meq/l, with a mean value of 29.95 meq/l. Chloride ( $\left.\mathrm{Cl}^{-}\right)$ions are one of the anions in irrigation water responsible for the potential of the water phytotoxicity. The normal and safe limit for chloride ions in irrigation water should not exceed 0.85meq/l (Landon, 1991).

\section{Soluble sulphate:}

Sulphate $\left(\mathrm{SO}_{4}{ }^{2-}\right)$ is one of the major anion occurring in natural waters. The permissible limit of sulphate $\left(\mathrm{SO}_{4}{ }^{2-}\right)$ is $20.8 \mathrm{meq} / \mathrm{L}$ according to FAO., (1985). The sulphate $\left(\mathrm{SO}_{4}{ }^{2-}\right)$ concentrations in well water ranged from 0.01 to $6.47 \mathrm{meq} / \mathrm{l}$, with mean value 2.53 , from the studied samples fall within the desirable limit.

\section{SAR values:}

The SAR values ranged between 1.77 and 18.37 with a mean value of 9.11. The limit recommended of SAR by the FAO, (1985) for irrigation water is (6.0-12.0). The SAR relates the relative concentration of $\mathrm{Na}$ to the combined concentrations of $\mathrm{Ca}$ and $\mathrm{Mg}$ ions. Increasing sodicity hazards may be associated with values exceeding 6. As SAR is a factor of sodium against calcium and magnesium, the high values recorded may not be a surprise as the sodium values are also relatively high. The results reveal that water may have the potential to be hazardous in some locations to the soil as well as to the crop grown, because the two most important parameters used in assessing the safety of irrigation water; namely, Water salinity $\left(E C_{w}\right)$, Sodium ions and the associated SAR are above the safe limits.

\section{Status of boron in well water of Ismailia Governorate area}

Boron is widely distributed in surface water and groundwater. The boron concentrations vary greatly depending on boron content of local geologic formations and anthropogenic sources of boron. Boron is naturally released to soil and water by rainfall, weathering of boron - containing minerals, desorption from clays and decomposition of boron containing organic matter (Deshmukh, 2015). Due to over irrigation the soils from the well of Ismailia area are suffering from the problems like salinization and alkalization. To minimize their problems and considering the importance of boron in the fertility of soils, it was decided to estimate the boron concentration in the groundwater from Ismailia area. 100 well water samples were analyzed for B (Table, 2). The boron concentrations ranged from 0.54 to $2.32 \mathrm{mg} / \mathrm{l}$, with a mean value of $1.19 \mathrm{mg} / \mathrm{l}$. It is seen from the above table that the boron content in $39 \%$ samples was below $1 \mathrm{ppm}$. This indicates that $39 \%$ samples have lower values of boron thereby reflecting less toxicity hazard, $53 \%$ between 1 to $2 \mathrm{ppm}$ boron (medium) and $8 \%$ over $2 \mathrm{ppm}$ boron (high). The high concentrations of $B$ are not expected to cause any toxicity for plant grown in Ismailia soils. This is attributed to B precipitates as calcium borate in soils (Gupta, 1974). The possible means to counteract the toxicity of boron is through proper selection of crops. Alfalfa, wheat, barley, oats, cotton, sugar beet, sorghum and maize are reported to be tolerant to boron (5-10 mg/l). The oil seeds, legumes, citrus and horticultural plants are in general sensitive to boron. The tolerance of crops to boron increases in the presence of soluble calcium, nitrogenous and phosphates fertilizers and decreases with increase in salinity (Gupta, 1974). Therefore, adequate fertilization could help in minimizing boron toxicity. However, it is further inferred that boron is in toxic concentration in saline groundwater from irrigated agriculture possibly due to restricted leaching. 
However, high levels of boron in saline soils can be easily reduced by leaching alone and in alkali soils by leaching after treatment with gypsum.

\section{Assessment of soil quality}

The results of the soils analysis of the various collected samples are presented in Table (4). The results include soil pH, soil salinity, (ECe), chlorides, sulphate, carbonate and bicarbonates, calcium, magnesium, potassium, sodium.

\section{Soil salinity (ECe)}

Electrical conductivity of soil saturation paste extracts (ECe) for each soil according to depth was presented in Table (4). The ECe of soil irrigated with well water ranged from 0.47 to $22.3 \mathrm{dS} / \mathrm{m}$, with a mean value of $5.03 \mathrm{dS} / \mathrm{m}$. However, even when water with a relatively low level of salinity is used for irrigation, soil salinity can increase under arid conditions. This is because of salts accumulations during the weathering process and was not leached from the root zone due to low precipitation. When irrigation is introduced, the salts present in arid soils become soluble and are redistributed within the root zone (Ganjegunte et al., 2017). Moreover, the amount of irrigation is not sufficient to overcome the high potential evapotranspiration demands resulting in accumulation of salts close to surface due to evapo-concentration. For example, the sandy textured nature of the soil as found in study area of Ismailia Governorate (no shown data) may necessitate higher irrigation frequency which in semi-arid climate like the area under study may not be desirable because of the tendency of excessive evaporation which may precipitate salts on the surface of the soil and which may be disadvantageous to non-tolerant varieties. As expected, mean of root zone soil salinities decreased depending on soil depth. Ben Ahmed et al. (2012) investigated the effects of saline irrigation water on soil salinity distribution and some physiological traits. They concluded that saline water irrigation has led to a significant increase in soil salinity; soil salinity and soil moisture variations were not only dependent on water salinity level but are also controlled by a multitude of factors particularly the soil texture, the distance from the irrigation source and climatic conditions (rainfall pattern, temperature average).

\section{pH Values:}

Data in Table (4) show that the pH of soil irrigated with well water ranged from 8.10 to 8.70 with a mean value of 8.28. The $\mathrm{pH}$ readings across the soil profile depth were slightly alkaline for almost profile of soil under study. The presence of higher concentrations of carbonates and bicarbonates in the soil further supports the alkalinity in the soil because it implies that most of the dissolved carbon dioxide and carbonates must have been increased to either carbonic acid $\left(\mathrm{H}_{2} \mathrm{CO}_{3}\right)$ or in the transitional state of bicarbonate. The slightly alkaline nature of the soil will not enhance the availability of nutrients and may further facilitate the solubilization of sodium ions which are the primary agents of salinization and alkalization in irrigated soils (Alhasn, 1996).

\section{Soluble cations and anions:}

The sodium concentrations of soil irrigated with well water ranged from 2.80 $\mathrm{meq} / \mathrm{l}$ to $136.1 \mathrm{meq} / \mathrm{l}$, with mean value 27.65 meq/l. The higher sodium concentrations and higher concentration of chloride makes the salinity in the soil to be in a form of sodium chloride $(\mathrm{NaCl})$. 
Table (4): Chemical analysis of the soil water paste extract and pH of Ismailia soil samples.

\begin{tabular}{|c|c|c|c|c|c|c|c|c|c|c|c|c|}
\hline \multirow{2}{*}{ No } & \multirow{2}{*}{$\begin{array}{c}\text { Depth } \\
\text { Cm }\end{array}$} & \multirow{2}{*}{ P } & \multirow{2}{*}{$\begin{array}{c}\mathrm{EC} \\
\mathrm{dS} / \mathrm{m}\end{array}$} & \multirow{2}{*}{ pH } & $\mathrm{Ca}^{++}$ & $\mathbf{M g}^{++}$ & $\mathrm{Na}^{+}$ & $\mathrm{K}^{+}$ & $\mathrm{CO}_{3}=$ & $\mathrm{HCO}_{3}$ & $\mathrm{Cl}^{-}$ & so \\
\hline & & & & & \multicolumn{8}{|c|}{ meq/l } \\
\hline \multirow[t]{2}{*}{1} & $0-20$ & 20.00 & 1.65 & 8.40 & 3.50 & 4.50 & 7.80 & 0.33 & \begin{tabular}{|l|}
0.00 \\
\end{tabular} & 3.00 & 12.70 & 0.43 \\
\hline & \begin{tabular}{|l|}
$20-40$ \\
\end{tabular} & 21.00 & 1.42 & 8.40 & 3.00 & 4.50 & 5.80 & .38 & 0.00 & 3.00 & 7.80 & .88 \\
\hline \multirow[t]{2}{*}{2} & $0-20$ & 25.00 & 1.79 & 8.20 & 4.50 & 2.50 & 80 & 18 & .00 & .10 & 14.70 & .18 \\
\hline & \begin{tabular}{|l|}
$20-40$ \\
\end{tabular} & 23.00 & 1.59 & 8.20 & 3.50 & 2.50 & 9.50 & 13 & 0.00 & 2.60 & 12.70 & .33 \\
\hline \multirow[t]{2}{*}{3} & $0-20$ & 24.50 & 1.21 & 8.30 & 2.50 & 3.50 & 5.80 & 0.15 & 0.00 & 3.00 & 6.90 & 2.05 \\
\hline & \begin{tabular}{|l|}
$20-40$ \\
\end{tabular} & 24.00 & 1.13 & 8.10 & & 2.50 & 530 & 13 & 0.00 & 3.00 & 6.40 & .53 \\
\hline \multirow[t]{2}{*}{4} & $0-20$ & 20.50 & 47 & 8.20 & & & 90 & & & & 00 & 01 \\
\hline & \begin{tabular}{|l|}
$20-40$ \\
\end{tabular} & 23.00 & 0.71 & 8.40 & 2.00 & 1.20 & 50 & 16 & .00 & .50 & 4.00 & 36 \\
\hline \multirow[t]{2}{*}{5} & $0-20$ & 21.50 & 1.59 & 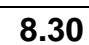 & 3.50 & 4.00 & 60 & 56 & .00 & .50 & 12.00 & \\
\hline & \begin{tabular}{|l}
$20-40$ \\
\end{tabular} & 22.50 & 1.93 & 8.10 & 7.00 & 5.00 & .00 & .94 & 0.00 & 2.00 & 2.00 & .94 \\
\hline \multirow[t]{2}{*}{6} & $0-20$ & 24.00 & 1.35 & 8.20 & 2.50 & 3.5 & 6.7 & 0.23 & 0.00 & 2.50 & 10.00 & .43 \\
\hline & \begin{tabular}{|l|}
$20-40$ \\
\end{tabular} & 21.00 & 1.65 & 8.50 & 300 & & 4.8 & 1.50 & 200 & 2.50 & 9.50 & .80 \\
\hline \multirow[t]{2}{*}{7} & $0-20$ & 23.00 & 11 & 8.3 & & & & & & & 7.50 & \\
\hline & \begin{tabular}{|l|}
$20-40$ \\
\end{tabular} & 22. & & 8. & & & 2 & & & & 6.50 & \\
\hline \multirow[t]{2}{*}{8} & $0-20$ & 21. & & 8 & 2 & & $\varepsilon$ & & & & 50 & \\
\hline & \begin{tabular}{|l|}
$20-40$ \\
\end{tabular} & 23. & & & 50 & & & & & 0 & 2.00 & \\
\hline \multirow[t]{2}{*}{9} & $0-20$ & 6 & & & 30.50 & 25.50 & (n) & U & & & 3.00 & \\
\hline & \begin{tabular}{|l|}
$20-40$ \\
\end{tabular} & 48.00 & 2.46 & 8.40 & 400 & & 16.50 & 0.19 & 0. & 2 & 22.00 & 19 \\
\hline \multirow[t]{2}{*}{10} & & & & & & & & & & & 18.00 & \\
\hline & \begin{tabular}{|l|}
$20-40$ \\
\end{tabular} & 22 & & & & & & & & & 50 & \\
\hline \multirow[t]{2}{*}{11} & $0-20$ & 25. & 1. & 8. & & & & & 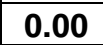 & 50 & 50 & \\
\hline & \begin{tabular}{|l|}
$20-40$ \\
\end{tabular} & 24. & & & & & & & & & 00 & \\
\hline 12 & $0-20$ & 25. & & & & & & & & & .00 & \\
\hline & \begin{tabular}{|l|}
$20-40$ \\
\end{tabular} & 22.50 & 9 & 8.20 & 22.50 & 22.00 & 0 & 43 & 0.0 & 3.5 & 71.60 & 53 \\
\hline 13 & $0-20$ & 25.00 & 4.75 & 8.20 & 18.00 & 14.50 & 1000 & 0.36 & 0 & 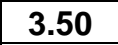 & 12.00 & \\
\hline & 20 & & & & & & & & & & & \\
\hline 14 & $0-20$ & 24. & & 8 & & & 22. & & & & 50 & \\
\hline & \begin{tabular}{|l|}
$20-40$ \\
\end{tabular} & 23. & 6.87 & 8. & 11.50 & 14. & 41. & 0 & 0 & 0 & 8.50 & .45 \\
\hline 15 & $0-20$ & 21. & & 8.2 & 10.00 & & & & & 0 & 0.50 & .07 \\
\hline & \begin{tabular}{|l|}
$20-40$ \\
\end{tabular} & & & & & & & & & 5. & 2.50 & .16 \\
\hline 16 & $0-20$ & 23.00 & 4.65 & 8.30 & 16.50 & 12.70 & 30 & 0.59 & 0 & 4.00 & 40.20 & .89 \\
\hline & \begin{tabular}{|l|}
$20-40$ \\
\end{tabular} & & & 8.20 & 12.00 & & 46,70 & 0.97 & & 2.50 & 70.70 & 77 \\
\hline 17 & & & & & & & & & & & & \\
\hline & \begin{tabular}{|l|}
$20-40$ \\
\end{tabular} & 21. & & 8 & 11 & 14 & 40 & & & 0 & 2.10 & \\
\hline 18 & $0-2$ & 23 & & 8 & & & & 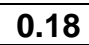 & 8 & 3. & 00 & 28 \\
\hline & \begin{tabular}{|l|}
$20-40$ \\
\end{tabular} & & & 8.1 & & & & & & 4. & 5.00 & .06 \\
\hline 19 & $0-20$ & 22.50 & 6.10 & 8.10 & 13.00 & 13.00 & 33.50 & 1.30 & 0.00 & 4.00 & 53.50 & 3.30 \\
\hline & \begin{tabular}{|l|}
$20-40$ \\
\end{tabular} & 25.50 & 9.13 & 8.50 & 15.50 & 13.50 & 60.20 & 1.10 & 0 & 3.50 & 35.50 & .30 \\
\hline 20 & $0-20$ & 22. & & 8. & & & & & & 2. & 3.70 & .07 \\
\hline & \begin{tabular}{|l}
$20-40$ \\
\end{tabular} & 21. & & & & & & & & 2 & 14.40 & \\
\hline 21 & & 28. & 1.20 & 8.5 & & 29 & 89 & & 2 & 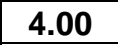 & .50 & .16 \\
\hline & \begin{tabular}{|l|}
$20-40$ \\
\end{tabular} & \begin{tabular}{|l|}
27 \\
\end{tabular} & 030 & 00 & 0 & 43.50 & & 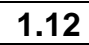 & & 4 & .50 & .72 \\
\hline 22 & $0-20$ & 2 & & 8.30 & 0 & 12.50 & 33.40 & 1.30 & 0 & 4.00 & 53.40 & .80 \\
\hline & \begin{tabular}{|l|}
$20-40$ \\
\end{tabular} & 21.00 & 4.72 & 8.50 & 9.50 & 8.00 & 26.30 & 1.30 & \begin{tabular}{|l|}
0.00 \\
\end{tabular} & 4.60 & 39.60 & 0.90 \\
\hline 23 & $0-20$ & 32.50 & 4.63 & 8.10 & 16.50 & 12.50 & 15.10 & 0.59 & \begin{tabular}{|l|}
0.00 \\
\end{tabular} & 4.00 & 10.00 & 0.69 \\
\hline & \begin{tabular}{|l|}
$20-40$ \\
\end{tabular} & 23.5 & $\mid 10.10$ & 8.50 & 27.00 & 20.50 & 51. & 1.70 & 0. & 3. & & 1.30 \\
\hline 24 & $0-20$ & 23.00 & 2.20 & 8.2 & & 4. & & 0.20 & \begin{tabular}{|l|}
0.00 \\
\end{tabular} & 2.50 & 6.80 & 1.60 \\
\hline & $20-40$ & 25.50 & 2.4 & 8.1 & & & 16.50 & 0.19 & 0.0 & 2.00 & 22.00 & 0.09 \\
\hline 16 & & & & 8. & & & & & 0.00 & 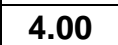 & 4.00 & 1.01 \\
\hline & $20-40$ & 26.80 & 3.36 & 8.10 & 7.00 & 6.00 & 19.70 & 0.49 & \begin{tabular}{|l|}
0.00 \\
\end{tabular} & 3.50 & 22.50 & 7.19 \\
\hline
\end{tabular}


W. E. Ahmed, et al.,

Table (4): Cont.

\begin{tabular}{|c|c|c|c|c|c|c|c|c|c|c|c|c|}
\hline \multirow[b]{2}{*}{ No } & \multirow{2}{*}{$\begin{array}{c}\text { Depth } \\
\mathrm{Cm}\end{array}$} & \multirow{2}{*}{ SP } & \multirow{2}{*}{$\begin{array}{c}E C \\
d S / m\end{array}$} & \multirow[b]{2}{*}{ pH } & $a++$ & lg++ & $\mathrm{Ja+}$ & $\mathrm{K}+$ & $\mathrm{CO} 3=$ & HCO3- & $\mathrm{Cl}-$ & SO4= \\
\hline & & & & & \multicolumn{8}{|c|}{ meq/l } \\
\hline \multirow[t]{2}{*}{26} & $0-20$ & 20.00 & 1.25 & \begin{tabular}{|l|}
8.40 \\
\end{tabular} & 4.00 & 3.50 & 4.74 & 0.46 & 0.00 & 2.50 & 7.50 & 2.70 \\
\hline & \begin{tabular}{|l}
$20-40$ \\
\end{tabular} & 20.50 & 1.46 & \begin{tabular}{|l|}
8.20 \\
\end{tabular} & 5.00 & 5.50 & 3.20 & 0.65 & 0.00 & 3.00 & 8.00 & 3.35 \\
\hline \multirow[t]{2}{*}{27} & $0-20$ & 21.50 & 1.96 & \begin{tabular}{|l|}
8.30 \\
\end{tabular} & 6.50 & 3.00 & 9.30 & 0.46 & 0.00 & 2.50 & 16.00 & 0.76 \\
\hline & $20-40$ & 24.50 & 5.17 & 8.20 & 9.00 & 7.50 & 33.30 & 0.33 & 0.00 & 2.00 & 48.00 & 0.13 \\
\hline \multirow[t]{2}{*}{28} & $0-20$ & 21.50 & 4.62 & \begin{tabular}{|l|}
8.50 \\
\end{tabular} & 9.50 & 8.00 & 26.20 & 1.30 & 0.00 & 4.50 & \begin{tabular}{|l|}
39.50 \\
\end{tabular} & 1.00 \\
\hline & $20-40$ & 21.00 & 0.15 & 8.20 & 7.50 & 5.50 & 21. & 1.50 & 0.00 & 50 & 32.00 & 50 \\
\hline \multirow[t]{2}{*}{29} & $0-20$ & 21.50 & 6.75 & \begin{tabular}{|l|}
8.20 \\
\end{tabular} & 13.00 & 11.00 & 37.90 & 2.56 & 0.00 & .00 & 57.00 & .46 \\
\hline & \begin{tabular}{|l}
$20-40$ \\
\end{tabular} & 22.50 & \begin{tabular}{|l|l|}
12.35 \\
\end{tabular} & \begin{tabular}{|l|}
8.30 \\
\end{tabular} & 23.50 & 19.00 & 72.30 & 2.20 & 0.00 & .50 & 106.00 & 6.50 \\
\hline \multirow[t]{2}{*}{30} & $0-20$ & 21.50 & 1.43 & \begin{tabular}{|l|}
8.20 \\
\end{tabular} & 3.50 & 2.00 & 8.20 & 0.19 & .00 & .00 & 10.50 & 0.39 \\
\hline & $20-40$ & 21.00 & 2.16 & \begin{tabular}{|l|}
8.20 \\
\end{tabular} & 5.00 & 4.00 & 11.60 & 0.16 & 0.00 & .50 & 16.50 & 0.76 \\
\hline \multirow[t]{2}{*}{31} & $0-20$ & 24.00 & 3. & \begin{tabular}{|l|}
8.20 \\
\end{tabular} & 11.50 & 12.50 & 5.60 & 2.20 & 0.00 & 50 & 10.00 & \begin{tabular}{|l|l|}
17.30 \\
\end{tabular} \\
\hline & \begin{tabular}{|l|}
$20-40$ \\
\end{tabular} & 22.50 & 3.42 & \begin{tabular}{|l|}
8.20 \\
\end{tabular} & 11.00 & 13.50 & 6.30 & 2.50 & 0.00 & 00 & 12.00 & \begin{tabular}{|l|l|}
17.30 \\
\end{tabular} \\
\hline \multirow[t]{2}{*}{32} & $0-20$ & 24.10 & 93 & \begin{tabular}{|l|}
8.50 \\
\end{tabular} & 12.00 & 9.50 & 5.70 & 1.00 & .00 & 50 & 3.50 & 1.20 \\
\hline & \begin{tabular}{|l|}
$20-40$ \\
\end{tabular} & 23.80 & 46 & \begin{tabular}{|l|}
8.40 \\
\end{tabular} & 12.50 & 8.00 & 42.90 & 1.03 & 0.00 & 00 & 0.00 & 0.43 \\
\hline \multirow[t]{2}{*}{33} & $0-20$ & 27.00 & 2.68 & \begin{tabular}{|l|}
8.50 \\
\end{tabular} & 11.50 & 9.00 & 6.00 & 0.16 & 0.00 & 00 & 9.60 & 4.06 \\
\hline & \begin{tabular}{|l|}
$20-40$ \\
\end{tabular} & 27.50 & & \begin{tabular}{|l|}
8.20 \\
\end{tabular} & 13.50 & 8.50 & 5.30 & 0.20 & 0.00 & (n) & 17.00 & 7.00 \\
\hline \multirow[t]{2}{*}{34} & $0-20$ & 25 & & \begin{tabular}{|l|}
8.20 \\
\end{tabular} & 9.00 & 8.0 & 12.00 & 0.8 & 0 & & 22.50 & 82 \\
\hline & \begin{tabular}{|l|}
$20-40$ \\
\end{tabular} & 27.50 & 3.2 & \begin{tabular}{|l|}
8.30 \\
\end{tabular} & 11.00 & 8.0 & 12.00 & 0.89 & 0.00 & 50 & 2.00 & 39 \\
\hline \multirow[t]{2}{*}{35} & $0-20$ & 24.50 & 2.67 & \begin{tabular}{|l|}
8.30 \\
\end{tabular} & 6.00 & 6.00 & 14.00 & 0.62 & .00 & .00 & 7.00 & .62 \\
\hline & $20-40$ & 24.70 & 2.71 & \begin{tabular}{|l|}
8.20 \\
\end{tabular} & 50 & 7.00 & 1.60 & 1.10 & .00 & 00 & 6.00 & .20 \\
\hline \multirow[t]{2}{*}{36} & $0-20$ & 22.50 & 1.99 & \begin{tabular}{|l|}
8.30 \\
\end{tabular} & 6.50 & 6.00 & 6.10 & 1.08 & .00 & 50 & 11.50 & 4.68 \\
\hline & $20-40$ & 22.50 & & \begin{tabular}{|l|}
8.20 \\
\end{tabular} & 13.50 & 6.50 & 10.50 & 0.85 & .00 & & 23.00 & .85 \\
\hline 37 & $0-20$ & & & \begin{tabular}{|l|l|} 
\\
\end{tabular} & 0 & 6 & 1 & 0. & 0 & 00 & 5.20 & 3 \\
\hline & $20-40$ & 24.10 & 3.6 & \begin{tabular}{|l|}
8.20 \\
\end{tabular} & 3.0 & 8.3 & 19.00 & 0.4 & 0.00 & .00 & 6.00 & 11 \\
\hline 38 & $0-20$ & 26.50 & & \begin{tabular}{|l|}
8.40 \\
\end{tabular} & 3.00 & 7 & 9.20 & 0.7 & .00 & .50 & 2.50 & 2.97 \\
\hline & \begin{tabular}{|l|}
$20-40$ \\
\end{tabular} & 25.70 & 7.23 & \begin{tabular}{|l|}
8.10 \\
\end{tabular} & 18.50 & 8.50 & 43.10 & 0.95 & 0.00 & 50 & 63.00 & 3.55 \\
\hline 39 & $0-20$ & 23.50 & 5.10 & \begin{tabular}{|l|}
8.20 \\
\end{tabular} & 22.50 & 14.50 & 8.90 & 2.20 & 0.00 & 0 & 2.00 & 3.60 \\
\hline & \begin{tabular}{|l|}
$20-40$ \\
\end{tabular} & & & \begin{tabular}{|l|}
8.70 \\
\end{tabular} & 22 & 50 & & & & & 50 & \\
\hline 40 & $0-20$ & 22.70 & 4 & \begin{tabular}{|l|}
8.20 \\
\end{tabular} & 65 & 5 & 30.20 & 1. & 0.00 & 00 & 5.00 & 39 \\
\hline & \begin{tabular}{|l|}
$20-40$ \\
\end{tabular} & 21.00 & 4.3 & \begin{tabular}{|l|}
8.20 \\
\end{tabular} & 4.50 & 4.00 & 32.20 & 2.51 & 0 & .00 & 36.00 & 3.21 \\
\hline 41 & $0-20$ & 23.30 & & \begin{tabular}{|l|}
8.30 \\
\end{tabular} & 4.50 & 3.00 & 22.30 & 0.8 & 0 & 50 & 26.00 & 1.15 \\
\hline & \begin{tabular}{|l|}
$20-40$ \\
\end{tabular} & 24.30 & 7.73 & \begin{tabular}{|l|}
8.30 \\
\end{tabular} & 10.00 & 15.00 & 48.30 & 2.95 & 0.00 & .50 & 68.00 & 3.75 \\
\hline 42 & $0-20$ & 24.00 & & \begin{tabular}{|l|}
8.30 \\
\end{tabular} & 13.50 & 15.00 & 21.60 & 1.46 & 0.00 & 0 & 4.00 & .06 \\
\hline & $20-40$ & & & \begin{tabular}{|l|l|}
8.50 \\
\end{tabular} & 750 & 12 & 16.80 & & & & 50 & \\
\hline 43 & $0-20$ & 21 & ? & \begin{tabular}{|l|}
8.20 \\
\end{tabular} & 0 & 11.00 & 68 & 0 & 0 & .50 & 7.00 & 6 \\
\hline & \begin{tabular}{|l|}
$20-40$ \\
\end{tabular} & 20.00 & 35 & \begin{tabular}{|l|}
8.30 \\
\end{tabular} & 16.00 & 6.70 & 11.70 & 0.26 & 0 & 00 & 29.00 & 2.66 \\
\hline 44 & $0-20$ & 17.50 & 25 & \begin{tabular}{|l|}
8.30 \\
\end{tabular} & 8.00 & 6.70 & 9.40 & 0.30 & .00 & 00 & 16.40 & 4.00 \\
\hline & \begin{tabular}{|l|}
$20-40$ \\
\end{tabular} & 21.00 & 1.34 & \begin{tabular}{|l|}
8.20 \\
\end{tabular} & 2.80 & 2.00 & 7.20 & 0.26 & 0.00 & .00 & 8.00 & 0.26 \\
\hline 45 & $0-20$ & 22.50 & 3.89 & \begin{tabular}{|l|l|}
8.30 \\
\end{tabular} & 18.50 & 13.50 & 6.30 & 0.31 & 0.00 & 00 & 2.50 & \begin{tabular}{|l|l|}
14.11 \\
\end{tabular} \\
\hline & $20-40$ & & & 8.20 & 10.50 & & & & & & & \\
\hline 46 & $0-20$ & 24.8 & & 820 & 25 & 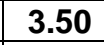 & 18.70 & 0.3 & 0 & 50 & 1.50 & .07 \\
\hline & \begin{tabular}{|l|}
$20-40$ \\
\end{tabular} & 20.0 & & \begin{tabular}{|l|}
8.20 \\
\end{tabular} & 2 & 9.50 & 43.60 & 0.67 & 0 & 00 & 60.00 & 0.86 \\
\hline 47 & $0-20$ & 24.00 & 5.70 & \begin{tabular}{|l|}
8.20 \\
\end{tabular} & 19.50 & 13.00 & 22.60 & 1.89 & .00 & .50 & 52.50 & 1.99 \\
\hline & \begin{tabular}{|l|}
$20-40$ \\
\end{tabular} & 21.50 & 2.87 & \begin{tabular}{|l|}
8.30 \\
\end{tabular} & 6.00 & 4.00 & 17.40 & 0.80 & 0.00 & 1.50 & 25.50 & 1.20 \\
\hline \begin{tabular}{|l|l|}
48 &
\end{tabular} & $0-20$ & 22.50 & 0.8 & \begin{tabular}{|l|l|}
8.20 \\
\end{tabular} & 2.00 & 1.00 & 4.60 & 0.20 & 0.00 & .00 & 5.50 & 0.30 \\
\hline & \begin{tabular}{|l|}
$20-40$ \\
\end{tabular} & 23.00 & 4.4 & 8.50 & 12.00 & 11.00 & 19.50 & 0.72 & 0.00 & 00 & 9.00 & .22 \\
\hline 49 & 20 & & & & & & & 0.18 & & 00 & 2.00 & .18 \\
\hline & \begin{tabular}{|l|}
$20-40$ \\
\end{tabular} & 23.10 & & 130 & 5.80 & 5.80 & 15.40 & 0.31 & .00 & 50 & 21.50 & 3.31 \\
\hline 50 & $0-20$ & 22.00 & 2.54 & \begin{tabular}{|l|l|}
8.20 \\
\end{tabular} & 4.50 & 3.50 & 15.90 & 0.33 & 0.00 & 4.00 & 20.00 & 0.23 \\
\hline & \begin{tabular}{|l}
$20-40$ \\
\end{tabular} & 20.00 & \begin{tabular}{|l|}
10.52 \\
\end{tabular} & \begin{tabular}{|l|}
8.40 \\
\end{tabular} & 31.50 & 19.50 & 51.70 & 1.54 & 0.00 & 5.50 & \begin{tabular}{|l}
97.00 \\
\end{tabular} & 1.74 \\
\hline
\end{tabular}


The effect of different well water quality and irrigation methods on some

Table (4): Cont.

\begin{tabular}{|c|c|c|c|c|c|c|c|c|c|c|c|c|}
\hline \multirow[b]{2}{*}{ No } & \multirow{2}{*}{$\begin{array}{c}\text { Depth } \\
\text { Cm }\end{array}$} & \multirow{2}{*}{ SP } & \multirow{2}{*}{$\begin{array}{c}\text { EC } \\
\mathrm{dS} / \mathrm{m}\end{array}$} & \multirow[b]{2}{*}{ pH } & $a++$ & $\mathrm{Mg}++$ & $\mathrm{Na}+$ & $\mathrm{K}+$ & $\mathrm{CO} 3=$ & $\mathrm{HCO} 3-$ & $\mathrm{Cl}-$ & SO4= \\
\hline & & & & & \multicolumn{8}{|c|}{ meq/l } \\
\hline \multirow[t]{2}{*}{51} & $0-20$ & 19.30 & 2.48 & 8.50 & 6.20 & 6.40 & 10.30 & 2.40 & 0.00 & 4.50 & 17.90 & 2.90 \\
\hline & \begin{tabular}{|l}
$20-40$ \\
\end{tabular} & 15.00 & 2.35 & 8.40 & 5.30 & 5.50 & 8.90 & 3.60 & 0.00 & 2.50 & 15.00 & 5.80 \\
\hline \multirow[t]{2}{*}{52} & $0-20$ & 21.70 & 2.31 & 8.20 & 7.00 & 6.00 & 8.20 & 0.74 & 0.00 & 4.00 & 16.00 & 1.94 \\
\hline & \begin{tabular}{|l|}
$20-40$ \\
\end{tabular} & 26.50 & 2.75 & 8.10 & 7.00 & 5.00 & 13.80 & 0.56 & 0.00 & 3.50 & 22.00 & 0.86 \\
\hline \multirow[t]{2}{*}{53} & $0-20$ & 29.70 & 5.37 & 8.50 & 6.50 & 8.00 & 37.10 & 0.67 & 0.00 & 3.50 & 47.00 & 1.77 \\
\hline & \begin{tabular}{|l|}
$20-40$ \\
\end{tabular} & 33.00 & 5.66 & 8.50 & 12.00 & 10.50 & 32.60 & 0.54 & 0.00 & 3.00 & 50.00 & 2.64 \\
\hline \multirow[t]{2}{*}{54} & $0-20$ & 28.10 & 7.64 & 8.30 & 10.50 & 11.50 & 52.70 & 1.03 & 0.00 & 4.00 & 64.00 & 7.73 \\
\hline & \begin{tabular}{|l}
$20-40$ \\
\end{tabular} & 21.80 & 7.68 & 8.20 & 21.00 & 10.50 & 43.60 & 0.56 & 0.00 & 4.50 & 65.00 & 6.16 \\
\hline \multirow[t]{2}{*}{55} & $0-20$ & 23.40 & 2.76 & 8.30 & 8.50 & 3.00 & 15.30 & 0.51 & 0.00 & 5.00 & 22.00 & 0.31 \\
\hline & \begin{tabular}{|l|}
$20-40$ \\
\end{tabular} & 23.00 & 6.11 & 8.20 & 11.00 & 8.00 & 41.00 & 0.50 & 0.00 & 6.00 & 48.00 & 6.50 \\
\hline \multirow[t]{2}{*}{56} & $0-20$ & 23.10 & 3.10 & 8.30 & 8.50 & 3.00 & 17.80 & 0.24 & 0.00 & 4.50 & 24.00 & 1.04 \\
\hline & $20-40$ & 21.10 & 2.41 & 8.30 & 6.50 & 3.00 & 13.90 & 0.13 & 0.00 & 7.00 & 16.00 & 0.53 \\
\hline \multirow[t]{2}{*}{57} & $0-20$ & 23.50 & 6.12 & 8.20 & 20.00 & 13.50 & 23.20 & 2.72 & 0.00 & .00 & 53.00 & 42 \\
\hline & \begin{tabular}{|l|}
$20-40$ \\
\end{tabular} & 23.10 & 6.82 & 8.70 & 23.90 & 15.00 & 26.90 & 2.15 & 0.00 & 5.00 & 56.20 & 6.75 \\
\hline \multirow[t]{2}{*}{58} & $0-20$ & 28.10 & 2.63 & 8.70 & 4.50 & 4.00 & 16.80 & 0.26 & 0.00 & 3.50 & 21.00 & 1.06 \\
\hline & \begin{tabular}{|l|}
$20-40$ \\
\end{tabular} & 21.50 & 3.85 & 8.20 & 5.50 & 6.50 & 25.30 & 0.26 & 0.00 & 3.00 & 33.50 & 1.06 \\
\hline \multirow[t]{2}{*}{59} & $0-20$ & 18.00 & 3.67 & 8.30 & 8.90 & $7.6 \mathrm{C}$ & 19.80 & 0.28 & 0.00 & 0 & 23.20 & 9.38 \\
\hline & $20-40$ & 17.80 & 3.88 & 8.20 & 9.00 & 7.90 & 21.60 & 0.18 & 0.00 & 4.00 & 28.00 & 6.68 \\
\hline \multirow[t]{2}{*}{60} & $0-20$ & 28.10 & 3.92 & 8.40 & 5.00 & 6.50 & 26.60 & 0.46 & 0.00 & .00 & 32.50 & 1.06 \\
\hline & $20-40$ & 29.70 & 5.18 & 8.40 & 12.50 & 12.00 & 25.90 & 0.61 & 0.00 & .00 & 46.50 & 1.51 \\
\hline \multirow[t]{2}{*}{61} & $0-20$ & 28.50 & 2.15 & 8.20 & 7.50 & 3.60 & 9.60 & 0.54 & 0.00 & 4.50 & 13.40 & 3.34 \\
\hline & $20-40$ & 28.50 & 2.08 & 8.40 & 7.00 & 3.5 & 0.00 & 1.00 & 0.00 & 4.00 & 12.50 & 3.30 \\
\hline 62 & $0-20$ & 19.80 & 2.3 & 8.20 & 4.00 & 3.0 & 15.90 & 0.41 & 0.00 & 5.1 & 18.00 & 0.31 \\
\hline & \begin{tabular}{|l|}
$20-40$ \\
\end{tabular} & 20.50 & 5.18 & 8.50 & 12.00 & 7.0 & 30.80 & 0.95 & 0.00 & 3.00 & 46.00 & 1.75 \\
\hline 63 & $0-20$ & 24.00 & 2.93 & 8.30 & 5.00 & 2.70 & 18.70 & 0.61 & 0.00 & 0 & 23.00 & 1.01 \\
\hline & $20-40$ & 22.00 & 1.86 & 8.20 & 2.50 & 4.50 & 9.70 & 0.46 & 0.00 & 3.50 & 13.50 & 0.16 \\
\hline 64 & $0-20$ & 23.30 & 2.53 & 8.20 & 8.00 & 2.00 & 14.60 & 0.31 & 0.00 & 7.00 & 17.50 & 0.41 \\
\hline & \begin{tabular}{|l|}
$20-40$ \\
\end{tabular} & 23.30 & 2 & 8.50 & 7.0 & 3.5 & 8.60 & 2.00 & 0.00 & 6.50 & 12.50 & 2.10 \\
\hline 65 & $0-20$ & 28.40 & 6.65 & 8.40 & 13.50 & 11.00 & 42.30 & 0.46 & 0.00 & 3.00 & 62.00 & 2.26 \\
\hline & \begin{tabular}{|l|}
$20-40$ \\
\end{tabular} & 37.00 & 14.10 & 8.20 & 19.50 & 14.50 & 103.60 & 1.95 & 0.00 & 3.50 & 132.00 & 4.05 \\
\hline 66 & $0-20$ & 26.40 & 1.81 & 8.20 & 4.00 & 1.50 & 11.90 & 0.23 & 0.00 & 2.50 & 14.50 & 0.63 \\
\hline & \begin{tabular}{|l|}
$20-40$ \\
\end{tabular} & 31.50 & 4.23 & 8.30 & 7.50 & 6.50 & 27.40 & 0.39 & 0.00 & 2.00 & 39.00 & 0.79 \\
\hline 67 & $0-20$ & 33.00 & 4.21 & 8.50 & 8.00 & 12.00 & 20.60 & 0.54 & 0.00 & 2.50 & 37.00 & 1.64 \\
\hline & $20-40$ & 29. & 2 & 8.40 & 4.50 & 400 & 16 & 0 & 0.00 & 0 & 19.50 & 0.19 \\
\hline 68 & $0-20$ & 25.40 & 15 & 8.40 & 4.0 & 3.5 & 8.7 & 0.21 & 0.00 & 4.00 & 11.00 & 1.41 \\
\hline & \begin{tabular}{|l|}
$20-40$ \\
\end{tabular} & 28.70 & 5.43 & 8.50 & 9.00 & 8.70 & \begin{tabular}{|l|l}
34.70 \\
\end{tabular} & 1.07 & 0.00 & 2.50 & 45.50 & 5.47 \\
\hline 69 & $0-20$ & 22.80 & 5.13 & 8.20 & 14.50 & 12.50 & 22.60 & 0.72 & 0.00 & 2.50 & 46.00 & 1.82 \\
\hline & \begin{tabular}{|l|}
$20-40$ \\
\end{tabular} & 23.10 & 22.30 & 8.30 & 47.50 & 34.00 & 128.60 & 1.12 & 0.00 & 2.50 & 203.00 & 5.72 \\
\hline 70 & $0-20$ & 17.20 & 5.48 & 8.20 & 8.00 & 7.00 & 38.80 & 0.87 & 0.00 & 5.00 & 46.50 & 3.17 \\
\hline & $20-40$ & 17.20 & & 8.40 & 15.50 & 7.0 & & 2.35 & 0.00 & - & 86.00 & 2.55 \\
\hline 71 & $0-20$ & 26.50 & 3.29 & 8.20 & 8.00 & 7.5 & 15.00 & 1.30 & 0.00 & 5.50 & 26.50 & 0.20 \\
\hline & \begin{tabular}{|l|}
$20-40$ \\
\end{tabular} & 27.50 & 3.63 & 8.20 & 8.50 & 6.40 & 21.40 & 1.28 & 0.00 & 6.50 & 29.00 & 2.08 \\
\hline 72 & $0-20$ & 28.00 & 6.92 & 8.20 & 13.00 & 12.20 & 42.80 & 1.24 & 0.00 & 3.50 & 64.50 & 1.24 \\
\hline & \begin{tabular}{|l|}
$20-40$ \\
\end{tabular} & 21.70 & 7.23 & 8.70 & 13.50 & 13.00 & 44.10 & 1.58 & 0.00 & 3.50 & 66.50 & 2.18 \\
\hline 73 & $0-20$ & 23.10 & 16.20 & 8.20 & 21.00 & 9.00 & 123.60 & 6.23 & 0.00 & 4.00 & 152.00 & 3.83 \\
\hline & $20-40$ & 23.60 & 13.20 & 8.30 & 20.00 & 7.30 & 108.60 & 3.20 & 0.00 & 6.00 & 129.60 & 3.50 \\
\hline 74 & $0-20$ & 24.60 & 4. & 8.20 & & 8.10 & 28.60 & 1.30 & 0.00 & 5.50 & 38.40 & 2.40 \\
\hline & $20-40$ & 24.10 & 4.98 & 8.20 & 10.00 & 9.00 & 29.00 & 1.26 & 0.00 & 6.00 & 41.00 & 2.26 \\
\hline 75 & $0-20$ & 25.00 & 11.95 & 8.20 & 34.00 & 29.00 & 53.40 & 1.82 & 0.00 & 5.00 & 109.00 & 4.22 \\
\hline & \begin{tabular}{|l|}
$20-40$ \\
\end{tabular} & 24.30 & 14.82 & 8.20 & 29.00 & 33.00 & 81.70 & 1.65 & 0.00 & 8.50 & 135.00 & 1.85 \\
\hline
\end{tabular}


W. E. Ahmed, et al.,

Table (4): Cont.

\begin{tabular}{|c|c|c|c|c|c|c|c|c|c|c|c|c|}
\hline \multirow[b]{2}{*}{ No } & \multirow{2}{*}{$\begin{array}{c}\text { Depth } \\
\text { Cm }\end{array}$} & \multirow[b]{2}{*}{ SP } & \multirow{2}{*}{\begin{tabular}{|c|}
$\mathrm{EC}$ \\
$\mathrm{dS} / \mathrm{m}$
\end{tabular}} & \multirow[b]{2}{*}{ H } & $a++$ & $g++$ & $\mathrm{Na}+$ & in & - & 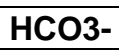 & Cl- & SO4= \\
\hline & & & & & \multicolumn{8}{|c|}{ meq/l } \\
\hline \multirow[t]{2}{*}{76} & $0-20$ & 22.00 & 3.35 & 8.10 & .50 & 50 & 16.10 & 0.36 & 0.00 & 3.00 & 28.50 & 0.96 \\
\hline & $20-40$ & 21.50 & 86 & 8.20 & .00 & 00 & 4.20 & & & 50 & 5.50 & \\
\hline \multirow[t]{2}{*}{77} & $0-20$ & 3.50 & 22 & 8.20 & 00 & 00 & .20 & & & & 3.00 & \\
\hline & $20-40$ & 22.50 & 4.78 & 8.20 & 50 & 7.40 & 30.70 & 76 & 00 & 00 & 8.20 & 16 \\
\hline \multirow[t]{2}{*}{78} & $0-20$ & 22.00 & 4.75 & 8.20 & 4.00 & 3.00 & 0 & .18 & & 0 & 9.90 & 28 \\
\hline & $20-40$ & 23.50 & 5.59 & 8.30 & 4.50 & 3.00 & & 1.17 & & & 47.50 & \\
\hline \multirow[t]{2}{*}{79} & $0-20$ & 25.0 & 5.80 & 8.10 & & 20.00 & & & & & & \\
\hline & $20-40$ & 20.00 & 12.35 & 8.10 & 7.50 & 18.00 & 82.40 & 110 & & & .00 & \\
\hline \multirow[t]{2}{*}{80} & $0-20$ & 24.30 & 7.95 & 8.20 & 6.00 & 0.50 & & 1.28 & & & 72.00 & \\
\hline & $20-40$ & 20.30 & 15.87 & 8.10 & 4.00 & 21.00 & 94.60 & 2.03 & .0 & 50 & 142.00 & .13 \\
\hline \multirow[t]{2}{*}{81} & $0-20$ & 25.40 & 3.76 & 8.20 & 2.00 & 11.00 & & .18 & & .00 & 34.50 & .08 \\
\hline & $20-40$ & 25.00 & 4.98 & 8.40 & 3.00 & 12.50 & & 121 & & & & \\
\hline \multirow[t]{2}{*}{82} & $0-20$ & 39.0 & 7.39 & 8.10 & & 14.00 & & & & & & \\
\hline & $20-40$ & 20.20 & 11.42 & 8.30 & .00 & 17.50 & & 1 & & & & \\
\hline \multirow[t]{2}{*}{83} & $0-20$ & 15.5 & 89 & 8.30 & .00 & 1.50 & 60 & $y$ & & 0 & .50 & \\
\hline & $20-40$ & 17.2 & 3 & 8.10 & 3.00 & 12.00 & & 6 & & 2 & 3.20 & 1.16 \\
\hline \multirow[t]{2}{*}{84} & $0-20$ & 22.00 & 4.35 & 8.30 & 3.00 & 11.30 & & .26 & & & 50 & 36 \\
\hline & $20-4$ & 2 & & 8.20 & & & & & & & & \\
\hline \multirow[t]{2}{*}{85} & & 2 & 6. & 8.40 & 00 & 13.00 & & & & & & \\
\hline & $20-40$ & 17.0 & 7.30 & 8.20 & .50 & 12.00 & & & & & & 11.23 \\
\hline \multirow[t]{2}{*}{86} & & 16.3 & & 8.20 & 50 & 3.00 & & & & & & \\
\hline & $20-40$ & 16.0 & 5 & 8.20 & 2.50 & 12.00 & 20 & 0.8 & & 0 & 00 & \\
\hline 87 & & 21.0 & 356 & 8.30 & 9.50 & & & & & & & \\
\hline & $20-4$ & 2 & & 8.2 & & & & & & & & \\
\hline 88 & $0-20$ & 18.0 & 5.98 & 8.2 & 0 & 12.00 & & 2.5 & & & & \\
\hline & $20-40$ & 23.00 & 17.30 & 8.40 & 3.50 & 14.90 & 116.80 & 2.9 & & 0 & 00 & 5 \\
\hline 89 & & 24.1 & & 8.30 & 1.00 & 00 & & & & & & \\
\hline & $20-40$ & 24.80 & 7.83 & 8.40 & \begin{tabular}{|l|}
18.50 \\
\end{tabular} & 9.50 & & 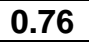 & & 00 & 50 & \\
\hline 90 & & 27.40 & & 8.20 & 4.50 & & & & & & & \\
\hline & 20. & 2 & & 8. & & & & & & & & \\
\hline 91 & & 20.8 & 5.9 & 8.1 & .50 & 70 & & - & & 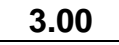 & & \\
\hline & $20-40$ & 28.1 & .3 & 8.2 & 7.50 & 5.00 & & 1.0 & & .0 & 50 & 5 \\
\hline 92 & & 16.0 & & 8.20 & 0 & 6.0 & & $?$ & & & & 22 \\
\hline & $20-40$ & 16.70 & 2.78 & 8.10 & .50 & 5 & & & & 00 & & \\
\hline 93 & & 2 & & 8. & & & & & & & & \\
\hline & $20-40$ & & & 89 & & 0 & & & & & & \\
\hline 94 & & 2 & 2.18 & 8.4 & 50 & 28 & & & & 50 & & \\
\hline & $20-40$ & 21.40 & & 8.2 & .00 & 8.5 & & $\leq$ & & 0 & & 22 \\
\hline 95 & $0-20$ & 22.50 & 6.18 & 8.30 & 6.00 & 4.50 & 50.20 & 0.85 & 0.0 & .50 & 4.00 & 0.05 \\
\hline & $20-40$ & 23.00 & 11.00 & 8.20 & .00 & 10.00 & & & & & & 50 \\
\hline 96 & & 2 & & 8. & & & & & & & & \\
\hline & $20-40$ & 19.5 & & 8.3 & 7.50 & & & 11 & & & & \\
\hline 97 & & 250 & & & & 0 & & & & 00 & 0 & 17.40 \\
\hline & $20-40$ & 26.4 & & & .50 & 17.50 & & & 0. & 0 & 0 & 2.17 \\
\hline 98 & $0-20$ & 20.50 & 6.72 & 8.20 & 8.50 & 9.00 & 30 & 0.51 & 0.00 & 50 & 00 & 0.81 \\
\hline & $20-40$ & 21.10 & 8.28 & 8.30 & 27.00 & 10.50 & 43.20 & 1.0 & 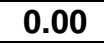 & .00 & 0 & 1.78 \\
\hline 99 & $0-20$ & 24.00 & 3.20 & 8.20 & & & & 0.3 & & 3.50 & & 3.43 \\
\hline & $20-40$ & 27.10 & & 8.10 & & 31. & & -1 & & & & .04 \\
\hline & & & & 8. & & & & & & & & 101 \\
\hline & $0-40$ & 24.80 & 16.36 & 8.20 & 8.00 & 10.50 & .60 & 1.5 & 0.00 & 6.00 & 153.00 & 1.61 \\
\hline
\end{tabular}


The calcium concentrations of soil irrigated with well water ranged from 1.0 meq/l to 50.0 meq/l, with a mean value of $11.74 \mathrm{meq} / \mathrm{l}$. The $\mathrm{Ca}^{2+}$ values across soil profile are generally higher because values greater than $20 \mathrm{mg} / \mathrm{kg}$ are generally considered high (Landon, 1991). The higher values calcium recorded here are a result of slightly alkaline $\mathrm{pH}$, because soils with $\mathrm{pH}$ values within the range of neutral to slightly alkaline are associated with high values of exchangeable calcium. However, the sandy textured nature of the soils and the need for frequent irrigation encourages its leaching, which explains its deviation from the assertion of its accumulation in arid and semi-arid environments.

The magnesium concentrations of soil irrigated with well water ranged from 0.50 meq/l to 43.5 meq/l, with a mean value of9.01 meq/l. The $\mathrm{Mg}^{2+}$ values are however within the medium range across the soil profile, values greater than $30-60 \mathrm{mg} / \mathrm{kg}$ are usually low-moderately sufficient in soil, according to (Landon, 1991).

The potassium concentrations of soil irrigated with well water ranged from $0.11 \mathrm{meq} / \mathrm{l}$ to $6.23 \mathrm{meq} / \mathrm{l}$, with a mean value of $0.92 \mathrm{meq} / \mathrm{l}$. The $\mathrm{K}^{+}$values are however fairly high. The high amount of $\mathrm{K}^{+}$in the soil may have also contributed to the low $\mathrm{Ca}^{2+}$ and $\mathrm{Mg}^{2+}$ values because of its better competitive ability for exchange sites, although their values are not extremely bad (Foloronsho, 1998). Both $\mathrm{Ca}^{2+}$ and $\mathrm{Mg}^{2+}$ are hovering above the $\mathrm{Na}^{+}$ concentration the advantage of which is their effect in lowering the SAR values. This may significantly offset the salinity condition in the soil.

The chloride concentrations of soil irrigated with well water ranged from 3.0 meq/l to $216.5 \mathrm{meq} / \mathrm{l}$, with a mean value of $42.81 \mathrm{meq} / \mathrm{l}$. Furthermore, the tendency for chloride build up in the soil may cause chloride ions approaching toxic levels, also lead to further salt formation.
Irrigation, fertilizer and agrochemicals management, as well as close monitoring of soil and water conditions should be adopted as strategies to maintain and/or improve the salinity status of the soil.

The bicarbonate in soil irrigated with well water ranged from 1.5 to $9.0 \mathrm{meq} / \mathrm{l}$, with a mean value of $3.88 \mathrm{meq} / \mathrm{l}$.

The sulphate $\left(\mathrm{SO}_{4}{ }^{2-}\right)$ concentrations in soil irrigated with well water ranged from 0.01 to $17.4 \mathrm{meq} / \mathrm{l}$, with a mean value of $2.56 \mathrm{meq} / \mathrm{l}$, from the studied samples fall within the desirable limit.

\section{Salt concentration factor (SCF)}

Data in Table (5) show that the salt concentration factor (SCF) of Ismailia soil under study ranged between 0.14 to 6.33 . The results showed that SCF was variable according to water and soil quality and irrigation methods. The highest value of salt concentration factor was 6.33 which does not meet with the higher value of irrigation water, because ECw for this area was $2.33 \mathrm{dSm}^{-1}$. On the other hand, $44 \%$ and $27 \%$ of salt concentration factor for two depth 0-20 and $20-40 \mathrm{~cm}$ were under $E C e / E C w=1$, because of their method of irrigation and quality of water that it shows leaching fraction. The results indicate that soil salinity does not necessarily increase with increasing salinity of irrigation water. This finding is rather surprising, because ECe should increase, in proportion to salinity of irrigation water if LF (leaching fraction) is the same. We must assume that soil salinity was affected by other factors besides salinity of irrigation water. Maskooni and Afzali (2015) showed that there is a polynomial relationship between $E C e$ and ECw, saturation water content and field moisture content in all of the lands. Also showed that a polynomial relationship between the SCF and saturation water content with high correlation in all of the sampling. 
W. E. Ahmed, et al.,

Table (5): The value of salt concentration factor (SCF) of studied soil of Ismailia area.

\begin{tabular}{|c|c|c|c|c|c|}
\hline No & $\begin{array}{c}\text { SCF } \\
(0-20 \mathrm{~cm})\end{array}$ & $\begin{array}{c}\text { SCF } \\
(20-40 \mathrm{~cm})\end{array}$ & No & $\begin{array}{c}\text { SCF } \\
(0-20 \mathrm{~cm})\end{array}$ & $\begin{array}{c}\text { SCF } \\
(20-40 \mathrm{~cm})\end{array}$ \\
\hline 1 & $\begin{array}{l}0.38 \\
\end{array}$ & 0.33 & 51 & 0.92 & 0.87 \\
\hline 2 & 0.35 & 0.31 & 52 & 1.01 & 1.20 \\
\hline 3 & 0.23 & 0.22 & 53 & 1.11 & 1.17 \\
\hline 4 & 0.14 & 0.21 & 54 & 1.71 & 1.72 \\
\hline 5 & 0.34 & 0.41 & 55 & 0.98 & 2.17 \\
\hline 6 & 0.29 & 0.35 & 56 & 1.19 & 0.92 \\
\hline 7 & 0.51 & 0.20 & 57 & 1.58 & 1.77 \\
\hline 8 & 0.37 & 0.46 & 58 & 0.90 & 1.32 \\
\hline 9 & 1.46 & 0.36 & 59 & 1.18 & 1.25 \\
\hline 10 & 0.42 & 0.18 & 60 & 1.36 & 1.80 \\
\hline 11 & 0.63 & 0.50 & 61 & 1.03 & 0.99 \\
\hline 12 & 0.25 & 1.75 & 62 & 0.65 & 1.41 \\
\hline 13 & 1.24 & 2.01 & 63 & 1.40 & 0.89 \\
\hline 14 & 1.01 & 1.95 & 64 & 1.26 & 1.07 \\
\hline 15 & 0.89 & 0.30 & 65 & 2.08 & 4.41 \\
\hline 16 & 0.90 & 1.47 & 66 & 0.63 & 1.47 \\
\hline 17 & 0.78 & 1.31 & 67 & 1.20 & 0.74 \\
\hline 18 & 0.49 & 0.86 & 68 & 0.66 & 2.29 \\
\hline 19 & 1.54 & 2.31 & 69 & 0.74 & 3.23 \\
\hline 20 & 1.16 & 0.91 & 70 & 1.13 & 2.01 \\
\hline 21 & 0.81 & 1.61 & 71 & 1.38 & 1.52 \\
\hline 22 & 0.88 & 0.68 & 72 & 1.49 & 1.56 \\
\hline 23 & 0.67 & 1.47 & 73 & 2.27 & 1.85 \\
\hline 24 & 1.40 & 1.53 & 74 & 1.58 & 1.68 \\
\hline 25 & 0.94 & 1.07 & 75 & 1.59 & 1.97 \\
\hline 26 & 0.93 & 1.09 & 76 & 0.99 & 0.25 \\
\hline 27 & 1.48 & 3.92 & 77 & 1.34 & 1.52 \\
\hline 28 & 1.60 & 1.30 & 78 & 1.50 & 1.76 \\
\hline 29 & 1.64 & 2.99 & 79 & 2.14 & 1.68 \\
\hline 30 & 0.66 & 0.99 & 80 & 1.22 & 2.43 \\
\hline 31 & 0.97 & 1.02 & 81 & 1.12 & 1.48 \\
\hline 32 & 1.82 & 1.70 & 82 & 1.70 & 2.62 \\
\hline 33 & 1.07 & 1.14 & 83 & 1.25 & 1.73 \\
\hline 34 & 0.94 & 1.03 & 84 & 1.92 & 2.30 \\
\hline 35 & 1.20 & 1.20 & 85 & 1.09 & 1.23 \\
\hline 36 & 1.24 & 2.00 & 86 & 1.35 & 1.59 \\
\hline 37 & 1.13 & 1.17 & 87 & 1.13 & 1.72 \\
\hline 38 & 1.20 & 1.69 & 88 & 1.42 & 4.10 \\
\hline 39 & 0.98 & 1.12 & 89 & 0.77 & 3.16 \\
\hline 40 & 1.58 & 1.57 & 90 & 1.00 & 2.31 \\
\hline 41 & 0.89 & 2.13 & 91 & 2.10 & 0.84 \\
\hline 42 & 1.58 & 1.09 & 92 & 1.24 & 0.89 \\
\hline 43 & 0.85 & 1.10 & 93 & 2.05 & 2.86 \\
\hline 44 & 1.04 & 0.54 & 94 & 0.82 & 2.62 \\
\hline 45 & 1.83 & 1.30 & 95 & 1.11 & 1.97 \\
\hline 46 & 0.93 & 2.29 & 96 & 1.64 & 1.66 \\
\hline 47 & 1.56 & 0.79 & 97 & 1.80 & 2.01 \\
\hline 48 & 0.38 & 2.06 & 98 & 2.66 & 3.27 \\
\hline 49 & 0.82 & 1.20 & 99 & 1.37 & 6.33 \\
\hline 50 & 0.88 & 3.64 & 100 & 1.02 & 5.11 \\
\hline
\end{tabular}



The spatial distribution of soil
salinity

Salinity is a serious problem in irrigated crop lands in arid and semi-arid regions so; evaluating the salinity distribution under various irrigation methods can be effective for salinity management. Comparison of surface, sprinkler and drip irrigation methods used soil salinity values in the $0-20$ and $20-40$ $\mathrm{cm}$ soil layer, expressed by the EC. The mean values of EC of soil were 3.94, 5.98 and 4.56 for drip, sprinkler and surface irrigation methods in depth $0-20 \mathrm{~cm}$, respectively. While, in soil depth $20-40 \mathrm{~cm}$ the mean values of EC were 6.78, 4.94 and 2.99 for drip, sprinkler and surface irrigation methods, respectively. The EC values are lower in case of surface irrigation than both of drip and sprinkler irrigation in most soils under study. As expected the difference observed between irrigation methods is mainly due to the difference in soil moisture content since the irrigation water supplies were similar. According to the soil moisture content values for each irrigation method, we can conclude that the surface irrigation keeps higher soil water content in the root zone which may help maintain continuous leaching of accumulated salts and thus reduce the soil salinity values. Oron et al. (2002) reported that high moisture content in the root zone with surface irrigation could increase the leaching process of accumulated salts; whereas the conventional drip irrigation facilitated sufficient leaching just below the emitter in the top soil layer, contributing to extra accumulation of salts in the active root zone of the crop and the soil salinity level remained high under the drip irrigation system. Singh and Bhumbla (1968) observed that the extent of salt accumulation depends on soil texture and reported that in soils containing less than $10 \%$ clay the ECe values remains lower than ECiw.
The spatial distribution of soil salinity in the soil horizons were found to be higher at shallow depths of $0-20 \mathrm{~cm}$ and decreasing gradually up to a depth of 20$40 \mathrm{~cm}$. This trend shown with surface and sprinkle irrigation method. Therefore, when the soil temperature raised some salinity bicarbonates were pushed to the surface of the soil. The ECe values were very much higher than the safe limit, much higher than the $4 \mathrm{dS} / \mathrm{m}$ describing the soil as being slightly alkaline (Landon, 1991). In drip irrigated method, the salinity distribution showed a different pattern from that observed in surface and sprinkler irrigation. Salinity was low in the surface layer $(0-20 \mathrm{~cm})$, and increased gradually with soil depth $(20-40 \mathrm{~cm})$.

Traditionally, irrigation was effected by flooding with water, but such methods allow significant losses of water to drainage and evaporation. The use of drippers reduces these losses but attracts additional costs for equipment. Consequently, farmers require good reasons if they are to invest in new technologies. Where water is in short supply, there may be clear advantages in using a drip system in preference to a more traditional method of water application, especially for a farmer who has to pay for water. These advantages may be greater if saline water can or has to be used. Saline water may be cheaper than fresh water and reducing water use by drip system which should reduce the quantity of water required for leaching. However, if drip systems are to be used, the farmer must be convinced that any additional costs would be covered by improvements in yield (Malash et al., (2008).

According to Table (6) and our results in Ismailia area we can classify of soil samples percent according to salinity class under different irrigation methods in surface and subsurface soil samples 
W. E. Ahmed, et al.,

(Table, 7). In surface soil samples, about $57 \%$ of soil samples occurred as none and slightly saline, moreover about $42 \%$ of subsurface soil samples were in moderately and strongly saline classes only $1 \%$ occurred in very strongly saline classes. About irrigation method effect, about 54.8, 42.9 and $70.0 \%$ were in none and slightly saline classes in surface soils under drip, sprinkler and surface irrigation method, respectively. While there were about $43.8,57.1$ and $30.0 \%$ occurred in moderately and strongly saline classes under drip, sprinkler and surface irrigation method, respectively.
As for, the subsurface samples about $44 \%$ of soil samples occurred as none and slightly saline, moreover about $52 \%$ of subsurface soil samples were in moderately and strongly saline classes only $4 \%$ occurred in very strongly saline classes. About irrigation method effect, about $39.5,42.8$ and $50.0 \%$ were in none and slightly saline classes in subsurface soils under drip, sprinkler and surface irrigation method, respectively. While there were about 52.1, 57.1 and $50.0 \%$ occurred in moderately and strongly saline classes under drip, sprinkler and surface irrigation method, respectively. Only, $5 \%$ occurred in very strongly saline classes for drip irrigation method.

Table (6). Soil salinity classes and crop growth*

\begin{tabular}{|l|c|l|}
\hline \multicolumn{1}{|c|}{ Soil Salinity Class } & $\begin{array}{c}\text { Conductivity of the } \\
\text { Saturation Extract (dS/m) }\end{array}$ & \multicolumn{1}{|c|}{ Effect on Crop Plants } \\
\hline Non saline & $0-2$ & Salinity effects negligible \\
\hline Slightly saline & $2-4$ & $\begin{array}{l}\text { Yields of sensitive crops may } \\
\text { be restricted }\end{array}$ \\
\hline Moderately saline & $4-8$ & $\begin{array}{l}\text { Yields of many crops are } \\
\text { restricted }\end{array}$ \\
\hline Strongly saline & $8-16$ & $\begin{array}{l}\text { Only tolerant crops yield } \\
\text { satisfactorily }\end{array}$ \\
\hline Very strongly saline & $>16$ & $\begin{array}{l}\text { Only a few very tolerant crops } \\
\text { yield satisfactorily }\end{array}$ \\
\hline
\end{tabular}

*FAO, 1988, Salt-Affected Soils and their Management, Bulletin 39.

Table (7): Classification of soil samples percent as salinity class under different irrigation methods in surface and sub surface soil samples.

\begin{tabular}{|l|c|c|c|c|c|}
\hline \multirow{2}{*}{$\begin{array}{l}\text { Irrigation } \\
\text { method }\end{array}$} & \multicolumn{5}{|c|}{ Salinity classes } \\
\cline { 2 - 6 } & Non saline & $\begin{array}{c}\text { Slightly } \\
\text { saline }\end{array}$ & $\begin{array}{c}\text { Moderately } \\
\text { saline }\end{array}$ & $\begin{array}{c}\text { Strongly } \\
\text { saline }\end{array}$ & $\begin{array}{c}\text { Very strongly } \\
\text { saline }\end{array}$ \\
\cline { 2 - 6 } Soil depth 0-20 cm \\
\hline Drip & 20.55 & 34.25 & 39.73 & 4.11 & 1.37 \\
\hline Sprinkler & 28.57 & 14.29 & 57.14 & - & - \\
\hline All & 10.00 & 60.00 & 25.00 & 5.00 & - \\
\hline \multicolumn{7}{|c|}{38.00} & 38.00 & 4.00 & 1.00 \\
\hline Drip & 19.00 & 38.00 & Soil depth 20-40 cm \\
\hline Sprinkler & 6.59 & 32.88 & 34.25 & 17.81 & 5.48 \\
\hline Surface & 28.57 & 14.29 & 57.14 & - & - \\
\hline All & 30.00 & 20.00 & 45.00 & 5.00 & - \\
\hline
\end{tabular}




\section{Correlation between selected well water parameters.}

The relationship between different water quality parameters was worked out through simple correlation analyses of the data (Table, 8).pH was negatively correlated with EC $\left(r=-0.306^{*}\right), \mathrm{Ca}^{++}(r=-$ $\left.0.290^{*}\right), \mathrm{Mg}^{++}\left(\mathrm{r}=-0.237^{*}\right), \mathrm{Na}^{+}\left(\mathrm{r}=-0.278^{*}\right), \mathrm{K}^{+}$ $(r=-0.038)$, ,Cl- $\left(r=-0.308^{*}\right)$, SAR $(r=-0.171)$, $B(r=-0.061)$, and positively correlated withHCO ${ }^{-}(r=0.066)$ and $\mathrm{SO}_{4}^{--}(r=0.034)$. Also, EC was positively correlated with $\mathrm{Ca}^{++}\left(r=0.885^{*+}\right), \quad \mathrm{Mg}^{++} \quad\left(r=0.813^{* *}\right), \quad \mathrm{Na}^{+}$ $\left(r=0.931^{* *}\right), \mathrm{K}^{+}\left(r=0.290^{*}\right), \mathrm{Cl}^{-}\left(r=0.996^{* *}\right)$, SAR $\left(r=0.605^{* *}\right), \quad B(r=0.178)$, and negatively correlated with $\mathrm{HCO}_{3}^{-}(r=0.046), \mathrm{SO}_{4}^{--}(r=-$ 0.121).It was noted that SAR and ECs significantly correlated with each other ( $r$ $=0.605^{*}$ ). It shows that SAR is a function of salinity i.e. the SAR together with total salt concentration (EC) may be used as an index to indicate salinity/sodicity hazard. However, $\mathrm{Ca}^{++}$was positively correlated with $\mathrm{Mg}^{++} \quad\left(r=0.905^{* *}\right), \quad \mathrm{Na}^{+} \quad\left(r=0.674^{\text {*t }}\right)$, $\mathrm{K}^{+}(r=0.182), \mathrm{Cl}-\left(r=0.874^{* *}\right), \mathrm{SO}_{4}^{--}(r=0.057)$ SAR $\left(r=0.215^{*}\right), B(r=0.193)$, and negatively correlated with $\mathrm{HCO}_{3}{ }^{-}(\mathrm{r}=-0.146)$. As for, $\mathrm{Mg}^{++}$was positively correlated with
$\mathrm{Na}^{+}\left(r=0.563^{* *}\right), \mathrm{K}^{+}\left(r=0.286^{*}\right), \mathrm{Cl}-\left(\mathrm{r}=0.810^{* *}\right)$, $\mathrm{SO}_{4}^{--}(r=0.005)$ SAR $(r=0.086), B(r=0.194)$, and negatively correlated with $\mathrm{HCO}_{3}{ }^{-}(\mathrm{r}=-$ 0.195).

Likewise, $\mathrm{Na}^{+}$was positively correlated with $\mathrm{K}^{+}\left(\mathrm{r}=0.272^{*}\right) \quad \mathrm{HCO}_{3}{ }^{-} \quad(r=0.060), \mathrm{Cl}-$ $\left(r=0.933^{* *}\right)$, SAR $\left(r=0.840^{* *}\right), B(r=0.134)$, and negatively correlated with $\mathrm{SO}_{4}^{--}(r=-$ $\left.0.214^{*}\right)$. The $\mathrm{Na}^{+}$and sodium adsorption ratio (SAR) showed a positive relationship with the groundwater EC (Ghassemi et al., 1995). Furthermore, $\mathrm{K}^{+}$was positively correlated with $\mathrm{Cl}-\left(\mathrm{r}=0.295^{*}\right)$ SAR $\left(r=0.204^{*}\right)$ and negatively correlated with $\mathrm{HCO}_{3}^{-} \quad(r=-0.048), \mathrm{SO}_{4}^{--}(r=-0.079) \quad \mathrm{B}(\mathrm{r}=-$ 0.011). However, $\mathrm{HCO}_{3}$ was negatively correlated with $\mathrm{Cl}-(\mathrm{r}=-0.055) \mathrm{SO}_{4}^{--}$( $r=-$ $\left.0.553^{\text {th }}\right) \quad B(r=-0.036)$ and positively correlated with SAR $\left(r=0.199^{*}\right)$. As for, $\mathrm{Cl}$ was positively correlated with SAR $\left(r=0.614^{* *}\right) \quad B(r=0.194)$ and negatively correlated with $\mathrm{SO}_{4}^{--}(r=-0.178)$.But, $\mathrm{SO}_{4}^{--}$ was negatively correlated with SAR ( $r=-$ $\left.0.319^{*}\right) \quad B(r=-0.156)$. Only, SAR was positively correlated with $B(r=0.047)$. The results are in conformity with results obtained by Ghodek, et al., (2016).

Table (8) Simple correlation between different parameters of well water

\begin{tabular}{|l|l|l|l|l|l|l|l|l|l|l|}
\hline & $\mathrm{pH}$ & $\mathrm{EC}$ & $\mathrm{Ca}^{++}$ & $\mathrm{Mg}^{++}$ & $\mathrm{Na}^{+}$ & $\mathrm{K}^{+}$ & $\mathrm{HCO}_{3}^{-}$ & $\mathrm{Cl}^{-}$ & $\mathrm{SO}_{4}^{--}$ & $\mathrm{SAR}$ \\
\hline $\mathrm{EC}$ & $-0.306^{*}$ & & & & & & & & & \\
\hline $\mathrm{Ca}^{++}$ & $-0.290^{*}$ & $0.885^{* *}$ & & & & & & & & \\
\hline $\mathrm{Mg}^{++}$ & $-0.237^{*}$ & $0.813^{* *}$ & $0.905^{* *}$ & & & & & & & \\
\hline $\mathrm{Na}^{+}$ & $-0.278^{*}$ & $0.931^{* *}$ & $0.674^{* *}$ & $0.563^{* *}$ & & & & & & \\
\hline $\mathrm{K}^{+}$ & -0.038 & $0.290^{*}$ & 0.182 & $0.286^{*}$ & $0.272^{*}$ & & & & & \\
\hline $\mathrm{HCO}_{3}^{-}$ & 0.066 & -0.046 & -0.146 & -0.195 & 0.060 & -0.048 & & & & \\
\hline $\mathrm{Cl}^{-}$ & $-0.308^{*}$ & $0.996^{* *}$ & $0.874^{* *}$ & $0.810^{* *}$ & $0.933^{* *}$ & $0.295^{*}$ & -0.055 & & & \\
\hline $\mathrm{SO}_{4}^{*-}$ & 0.034 & -0.121 & 0.057 & 0.005 & $-0.214^{*}$ & -0.079 & $-0.553^{* *}$ & -0.178 & & \\
\hline $\mathrm{SAR}$ & -0.171 & $0.605^{* *}$ & $0.215^{*}$ & 0.086 & $0.840^{* *}$ & $0.204^{*}$ & $0.199^{*}$ & $0.614^{* *}$ & $-0.319^{*}$ & \\
\hline $\mathrm{B}$ & -0.061 & 0.178 & 0.193 & 0.194 & 0.134 & -0.011 & -0.036 & 0.194 & -0.156 & 0.047 \\
\hline
\end{tabular}




\section{Correlation between selected soil properties.}

Correlations between selected soil properties are presented in Table (9). SP was positively and not significantly correlated with $\mathrm{pH}, \mathrm{EC}, \mathrm{Ca}^{++}, \mathrm{Na}^{+}, \mathrm{Cl}^{-}, \mathrm{HCO}_{3}{ }^{-}$ and significantly only with $\mathrm{Mg}^{++}\left(r=0.167^{*}\right)$ but negatively and not significantly correlated with $\mathrm{K}^{+}$and $\mathrm{SO}_{4}-$.Soil water content (which expressed as SP) increased with irrigation water salinity (EC). This result indicated that excessive irrigation with water of high salinity could affect the structural characteristics of soil to a great extent. These results are similar to those previously reported by Feng et al. (2011) explained that the higher soil water content in saline treatments resulted from the relatively low water consumption of vines under medium and high salinity. Jiang et al. (2010) found that severe salt stress markedly inhibited the water uptake and that more water was left in the soil. We speculate that the exchange and adsorption happens between the salt ions brought by the saline water and the soil colloid and the native ions of the soil during irrigation periods. The increasing sodium content enlarges the hydration degree of the soil particles, which easily results in the separation of those particles. Along with the water movement, the particles move down and deposit and then block the flow of water, decrease the actual discharge area of the water flow, form compacted weak water layer and reduce soil permeability. Ultimately, the deep percolation is reduced and the soil water content increases relatively. However, the effect of water salinity on soil water content is limited comprehensively. Also, EC was positively and significantly correlated with $\mathrm{Ca}^{++}$,
$\mathrm{Mg}^{++}, \mathrm{Na}^{+}, \mathrm{K}^{+}, \mathrm{Cl}^{-}, \mathrm{HCO}_{3}$-butpositively and not significantly correlated with $\mathrm{pH}$ and $\mathrm{SO}_{4}{ }^{--}$. In alkaline soils, $\mathrm{pH}$ usually increases with an increase in salinity due to the presence of sodium bicarbonate and carbonate (Gupta et al., 1989). However, Tan (1993) reported that increasing sodicity in soil does not necessarily yield a rise in $\mathrm{pH}$. Many sodic soils are neutral in reaction, whereas some are even acidic in reaction. The strongly alkaline reaction ( $\mathrm{pH}$ around 10) of most sodic soils is caused by alkalization during which sodium carbonate and bicarbonate are formed. Under less alkaline conditions, i.e. where calcium carbonate dominates the soil mineralogy, soil $\mathrm{pH}$ has been shown to drop with an increase in salinity (Lai and Stewart, 1990). However, pH was positively and not significantly correlated with $\mathrm{Ca}^{++}, \mathrm{Mg}^{++}, \mathrm{K}^{+}, \mathrm{Cl}^{-}$, but negatively and not significantly correlated with $\mathrm{Na}^{+}$, $\mathrm{HCO}_{3}{ }^{-}$and $\mathrm{SO}_{4}$. while, $\mathrm{Ca}^{++}$was positively and significantly correlated with $\mathbf{M g}^{++}, \mathrm{Na}^{+}$ $, \mathrm{K}^{+}, \mathrm{Cl}^{-}, \mathrm{HCO}_{3}{ }^{-}$and $\mathrm{SO}_{4}-$. As for, $\mathrm{Mg}^{++}$was positively and significantly correlated with $\mathrm{Na}^{+}, \mathrm{K}^{+}, \mathrm{Cl}^{-}$, and $\mathrm{SO}_{4}-$ but positively and not significantly correlated with $\mathrm{HCO}_{3}{ }^{-}$. Anywise, $\mathrm{Na}^{+}$was positively and significantly correlated with $\mathrm{K}^{+}, \mathrm{Cl}^{-}$, and $\mathrm{HCO}_{3}{ }^{-}$but positively and not significantly correlated with $\mathrm{SO}_{4}-$. Whatever, $\mathrm{K}^{+}$was positively and significantly correlated with $\mathrm{Cl}^{-}$, and $\mathrm{SO}_{4}{ }_{4}$-but positively and not significantly correlated with $\mathrm{HCO}_{3}{ }^{-}$. As well, $\mathrm{HCO}_{3}{ }^{-}$was positively and significantly correlated with $\mathrm{Cl}^{-}$, and but positively and not significantly correlated withSO ${ }_{4}^{--}$.Only, $\mathrm{Cl}-$ was positively and not significantly correlated withSO ${ }_{4}^{--}$.The results are in conformity with results obtained by Bikash et al,. (2000). 
Table (9) Simple correlation between selected soil properties.

\begin{tabular}{|l|c|c|c|c|c|c|c|c|c|}
\hline & $\mathrm{SP}$ & $\mathrm{EC}$ & $\mathrm{pH}$ & $\mathrm{Ca}^{++}$ & $\mathrm{Mg}^{++}$ & $\mathrm{Na}^{+}$ & $\mathrm{K}^{+}$ & $\mathrm{HCO}_{3}^{-}$ & $\mathrm{Cl}^{-}$ \\
\hline $\mathrm{EC}$ & 0.118 & & & & & & & & \\
\hline $\mathrm{pH}$ & 0.103 & 0.015 & & & & & & & \\
\hline $\mathrm{Ca}^{++}$ & 0.114 & $0.869^{* *}$ & 0.049 & & & & & & \\
\hline $\mathrm{Mg}^{++}$ & $0.167^{*}$ & $0.815^{* *}$ & 0.080 & $0.871^{* *}$ & & & & & \\
\hline $\mathrm{Na}^{+}$ & 0.100 & $0.959^{* *}$ & -0.008 & $0.713^{* *}$ & $0.644^{* *}$ & & & & \\
\hline $\mathrm{K}^{+}$ & -0.067 & $0.497^{* *}$ & 0.081 & $0.421^{* *}$ & $0.355^{* *}$ & $0.475^{* *}$ & & & \\
\hline $\mathrm{HCO}_{3}^{-}$ & 0.013 & $0.249^{* *}$ & -0.015 & $0.210^{*}$ & 0.126 & $0.263^{* *}$ & 0.124 & & \\
\hline $\mathrm{Cl}^{-}$ & 0.129 & $0.996^{* *}$ & 0.023 & $0.861^{* *}$ & $0.806^{* *}$ & $0.961^{* *}$ & $0.484^{* *}$ & $0.217^{*}$ & \\
\hline $\mathrm{SO}_{4}^{--}$ & -0.065 & 0.132 & -0.017 & $0.178^{*}$ & $0.206^{*}$ & 0.085 & $0.236^{*}$ & 0.017 & 0.063 \\
\hline
\end{tabular}

\section{Effect of Saline well water on Soil Salinity}

The general trend line showed that soil salinity increased with an increase in water salinity. Correlation coefficient $(r)$ between EC of irrigation water and EC of soil was $0.550^{* *}$. Results also showed that EC of irrigation water affected the soil properties, if the average salinity of the soil water is about three times the salinity of the irrigation water. This salinity, however, will vary with depth and method of irrigation the upper root zone will contain less salinity than the lower parts. Salts will normally be leached out of this upper root zone but accumulate to higher concentrations in the lower rooting zone. The extent of this accumulation will depend upon the leaching that takes place. According to Khan, et al., (2014) who reported that of water with low quality has a negative impact on the soil as a result of causing salinity and infiltration problems. Also, Hillel (1998) reported that salt in the irrigation water will eventually be transferred to the soil during irrigation, changing the concentration and composition of salt in the soil water. Since only pure water evaporates at the soil and plant surfaces it implies that the salt will remain in the soil, unless leaching occurs.
Thus, irrigation tends to concentrate the salt in soil water, which lowers the osmotic potential and hence the total soil water potential (matric plus osmotic) of the soil.

\section{REFERENCES}

Abid, M. (2000). Response of soils and crops to brackish irrigation waters. Ph.D. Thesis, Univ. Agric., Faisalabald, Pakistan.

Adamu, G.K. (2013). Quality of irrigation water and soil characteristics of Water irrigation project. American Journal of Engineering Research, vol.2, no.3, pp.59-68.

Alhasn, J. (1996). Determination of CEC and exchangeable bases $(\mathrm{Ca}, \mathrm{Mg}, \mathrm{K}$ and $\mathrm{Na}$ ) of soils from Sokoto-Rima River Basin at Kwalkwalawa", A BSc. project submitted to the department of soil science and Aric, Usman Dan Fodio University, Sokoto,

Ajayi, F., M. Nduru and A. Oningue (1990). Halting the salt that kills crops. African Farmer, no.4, pp.10-12.

Ayers, R.S. and D.W. Westecot .(1976) Water quality for agriculture irrigation. Food and Agric. Organ of U.N. Rome (29). 
Belan, F. I. (1985). Water treatment, Mir Publishers Moscow, USSR, pp.232.

Ben Ahmed, C., S. Magdich, B. Ben Rouina, M. Boukhris and F. Ben Abdullah (2012). Saline water irrigation effects on soil salinity distribution and some physiological responses of field grown Chemlali olive. Journal of Environmental Management.113: 538544.

Bikash, C.S., H. Michihiro and M.W. Zaman (2000). Suitability assessment of natural water in relation to irrigation and soil properties, Soil Science and Plant Nutrition, 46:4, 773-786.

Camp, C.R., E. J. Sadler, W. J. Busscher, R. E. Sojlka and D. L. Karrlin (2001). Experiencing with sprinkler irrigation for agronomic crops in the southeastern USA. In Micro irrigation for a Changing World: Conserving Resources/Preserving the Environment. Proc. of the Fifth International Micro irrigation Congress, ed. F. R. Lamm, 638-644. St. Joseph, Mich.: ASAE.

Chapman, H.D. and P.E. Pratt (1961). Methods for Analysis of Soils, Plants and Waters. Univ. of Calif, Div. of Agric. Sci.

Christenson, J.E., E.C. Olsen and L.S. Willardson (1977). Irrigation water quality evaluation, Journal of irrigation and Drain. Div., A and CIR 2.proc. paper 13015.

Danko, M.M. (1997). Comparative analysis of variables of irrigation water quality along river Rima. B. Agricultural project, Department of soil science and Agricultural engineering, Usman Dan Fodio Sokoto, pp.45,

Davis, S. W. and R.J.M. Dewest (1966). "Hydrology", John Willey and Sons, New York, pp. 463,.

Deshmukh, K.K. (2015). International science congress association status of boron in soil and groundwater from Sangamner area, Ahmednagar district,
Maharashtra India, Res. J. Recent. Sci. 4: 283-290.

El-Aassy, I. K., M. G. El-Feky, F. A. Issa, N. M. Ibrahim, O. A. Desouky and M. R. Khattab (2015). Characterization of groundwater and uranium isotopic ratios $(234 \mathrm{U} / 238 \mathrm{U})$ in some dogged and drilled wells from southwestern Sinai, Egypt. Water Utility Journal 9: 19-30.

FAO. (1985). Guidelines: land evaluation for irrigated agriculture. Soils Bulletin 55.Food and Agriculture Organization of the United Nations, Rome, Italy.

FAO. (1988). Salt-Affected Soils and their Management, Bulletin 39.Food and Agriculture Organization of the United Nations, Rome, Italy.

FAO. (1992). The use of saline waters for crop production - FAO irrigation and drainage paper 48. Food and Agriculture Organization of the United Nations, Rome, Italy.

Feng, D., J. P. Zhang and C. Y. Cao (2011). Soil water and salt migration under border irrigation with saline water. Journal of Soil and Water Conservation, 25(5): 48-52.

Foloronsho, E. (1998). Evaluation of soil fertility status Under Irrigation in Jakara River Valley, A case study of Air- Port Road-Katsina Road, Kano Metropolis, Post Graduate Diploma in Land Resources Thesis, Geography department, Bayero University, Kano,1998.

Ganjegunte, G.K., A. Ulery, G. Niu and Y. Wu. (2017). Effects of treated municipal wastewater irrigation on soil properties, switch grass biomass production and quality under arid climate .Ind. Crops Prod. 99:60-69.

Ghassemi, F., A.J. Jakeman and H.A. Nix (1995). Salinization of land and water resources, CABI international, UK

Ghodek, S.K., O.Y. Hirey and A.S. Gajare (2016). Quality of irrigation water from choker tensile of later district, Maharashtra. International Journal of 
Agriculture Sciences, Volume 8, Issue 49, pp.-2090-2095.

Grattan, S.R., C. Shannan, D.M. May and J.P. Mitchell (1996). Use of drainage water for irrigation of melons and tomatoes. California Agriculture, 41:27-28.

Grattan, S.R., C. Shennan, D. May, B. Roberts, M. Borin and M. Sattin (1994). Utilizing saline drainage water to supplement irrigation water requirements of tomato in a rotation with cotton. In: Proceedings of the 3rd congress of the European Society for Agronomy, Padova University, AbanoPadova, Italy, 18-22 September, pp 802-803

Gupta, I.C. (1974). Use of Saline water for irrigated soils in arid and semi-arid zones of Rajastha, Indian Journal of Agri. Research, 6(4), pp 207.

Gupta, R.K., R.R. Singh and I.P. Abrol (1989). Influence of simultaneous changes in sodicity and $\mathrm{pH}$ on the hydraulic conductivity of an alkali soil under rice culture. Soil Science 147(1): 28-33.

Hillel, D. (1998). Environmental Soil Physics. Academic Press, London.

Jiang, J., S. Feng and Z. Huo (2010). Effect of irrigation with saline water on soil water-salt dynamics and maize yield in arid Northwest China. Wuhan University Journal of Natural Sciences, 15(1): 85-92.

Khan, G.D., F. Akbar,T. Khan, W. Ullah, N. Naseebullah and B. Bismillah (2014). Assessment of Salinity and Alkalinity of Groundwater and It Relation to the Geochemical Properties of Soil in a Specific Site of Lasbela Region. Chemistry and Materials Research, 6 (4): 93-99.

Khandelwal, R.B. and P. Pal. (1993). Effect of salinity, sodicity and boron of irrigation water on the properties of different soils and yield of wheat
.Journal of Indian Society of Soil Science, 39:537-541.

Lai, R. and B.A. Stewart. (1990). Saltaffected soils. In Soil Degradation. Springer-Verlag: New York; 224-247.

Landon, J. R. (1991). Booker Tropical Soil Manual, John Wiley and Sons Inc., New York, (Ed),

Malash, N. M., T. J. Flowers and R. Ragab (2008). Effect of irrigation methods, management and salinity of irrigation water on tomato yield, soil moisture and salinity distribution. Irrig. Sci. 26:313-323

Maskooni, E. K. and S. F. Afzali (2015). The Relation between water salinity with some soil characteristics and soil Salinity potential estimated by using the salt concentration factor. J. Appl. Environ. Biol. Sci., 5(8S)91-97.

Miyamoto, S. and A. Chacon (2006). Soil salinity of urban turf areas irrigated with saline water. II. Soil factors. Landscape Urban Plan. 77:28-38.

Michael, A.M. (2008). Irrigation Theory and Practice, Second edition (revised and enlarged) Vikas Publishing House PVT. Ltd, Delhi, India. p.768.

Michael, A. M. (1985). Irrigation principles and practices, Vik as publishing house Itd, New Delhi, pp.702-720,

Miyamoto, S and A. Chacon (2006). Soil salinity of urban turf areas irrigated with saline water. II. Soil factors. Landscape Urban Plan. 77:28-38.

Moran, S.R., G. Groemewold and J.A. Cherry (2001). Hydro geologic and geochemical concepts and methods in overburden investigation for reclamations of mined land. North Delta Geol. Surv. Rept. Invest. 62,150 pp.

Oron, G., Y. DeMalach, L. Gillerman, I. David and S. Lurie (2002). Effect of water salinity and irrigation technology on yield and quality of pears. Biosyst . Eng. 81, 237-247. 
Perez, G., M.J. Martinez, J. Vidal and A. Sanchez (2003). The role of low quality irrigation water in the desertification of semi-arid zones in Murica, SE Spain. Geoderma , 21:109-125.

Ragab, R. (2005). Advances in integrated management of fresh and saline water for sustainable crop production: Modeling and practical solutions. International J Agric Water Manage (Special Issue) 78(1-2):1-164. Elsevier, Amsterdam

Sajadi, M., A. Zeinedini and S. Mahmudi (2012). Quality impacts of irrigation on soil properties and yield of pistachio in plain Robat Shahrbabak. Journal of Irrigation and Water Engineering, 7: 3646.

Sharma, B. R. (2001). Availability, status and development and opportunities for augmentation of groundwater resources in India. Proceeding ICARIWMI Policy Dialogue on Ground Water Management, November 6-7, 2001 at CSSRI, Karnal pp. 1-18.
Singah, B. R. (2000). Quality of irrigation water in Fadama lands North-western Nigeria, Ground and Surface Water in Kebbi State, Nig. J. Basic. And Apl. Sci., vol.9, pp.148,

Singh, B. and D.R. Bhumbla (1968). Effect of quality of irrigation water on soil properties. J. Res. Punjab Agric Univ. 5, 166-172.

Tan, H.K. (1993). Soil reaction. In Principles of Soil Chemistry, 2nd edn. Marcel Dekker: New York; 255-278.

Tiercelin, J. R. and A.Vidal (2006). Treaty of Irrigation, 2nd ed. Paris: Lavoisier.

Yildirim, O. and A. Korukcu (2000). Comparison of Drip, Sprinkler and Surface Irrigation Systems in Orchards. Faculty of Agriculture, University of Ankara, Ankara Turkey. 47p.

Zartman, R.E and M. Gicharu (1984). Saline irrigation water effects on soil chemical and physical properties. Soil Scenic Journal, 138(6): 417-422. 


\title{
تأثير جودة مياة الابار المختلفة وطرق الرى على بعض الخواص الكيميائية و توزيع
} الاملاح فى التربة فى المناطق الجافة: دراسة حالة لمحافظة الاسماعلية

\author{
وفائى الحسينى احمد ، خالد شعبان الحدق، مصطفى عبد العدل درويش

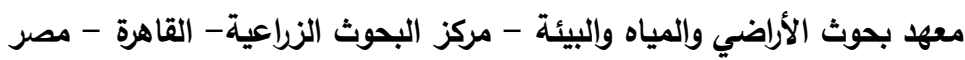

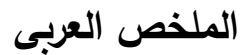

أجريت هذة الاراسة لتقييم توزيع الملوحة فى التربة تحت ظروف الرى بمياة الابار المختلفة الجودة وطرق الرى المختلفة فى بعض مناطق محافظة الاسماعلية. تم جمع عينات من التربة ومياة الابار من مائة موقع مختلف فى محافظة الاسماعلية.

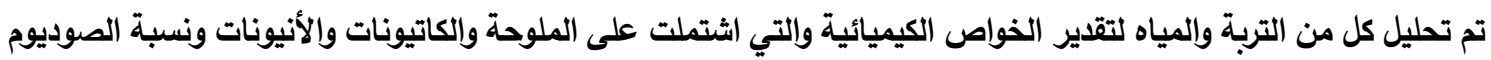

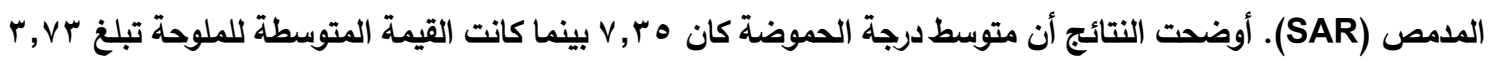

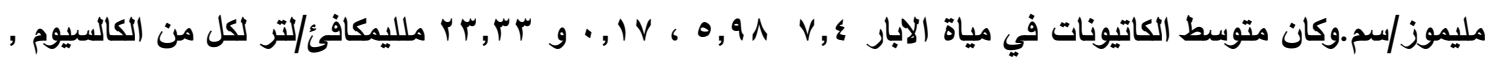

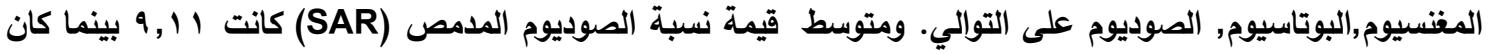

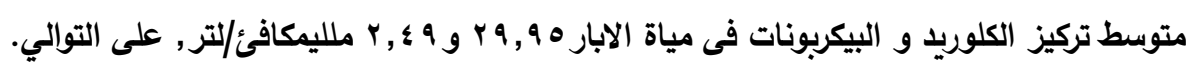

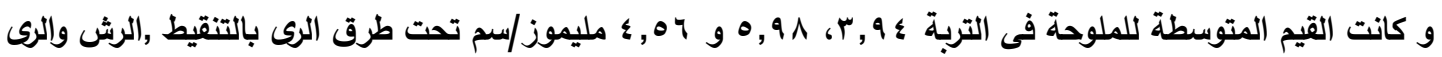

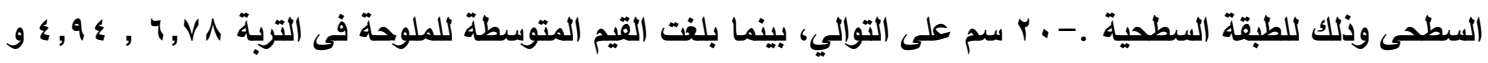

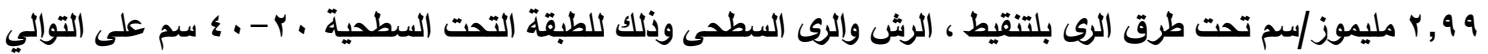

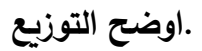

المكاني لملوحة التربة ان درجة الملوحة في آفاق التربة تكون أعلى في الأعماق الضحلة من · ·- ·. سم وتقل تدريجيا

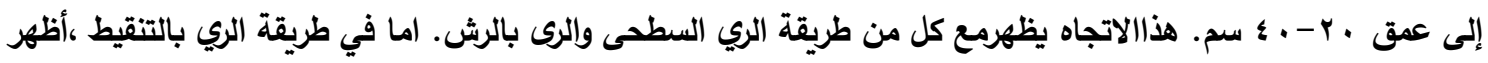

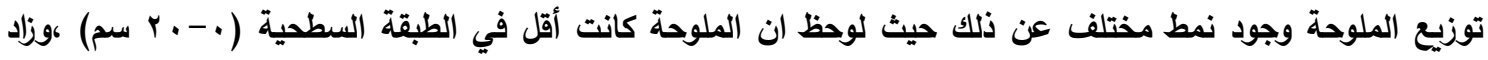

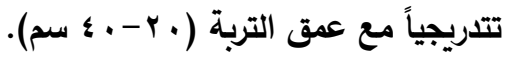

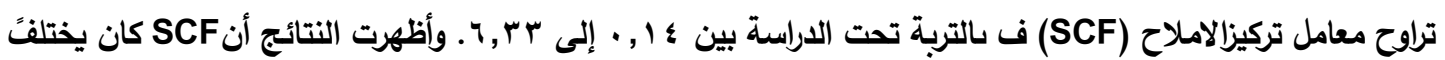
وفقاً لنوعية الماء والتربة وطرق الرئ تركية درجة ملوحة التربة EC ارتبط معنويا وايجابيا مع كل من الكالسيوم، المغنسيوم، البوتاسيوم، الصوديوم، الكلوريد والبيكربونات فى التربة ولكن ارتبط ايجابيا وغير معنوى مع كل من درجة الحموضة وتركيز ايون الكبريتات ـ بينما كان

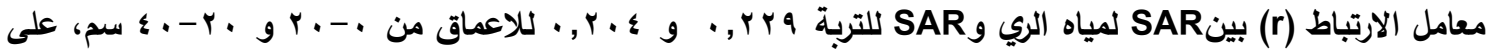

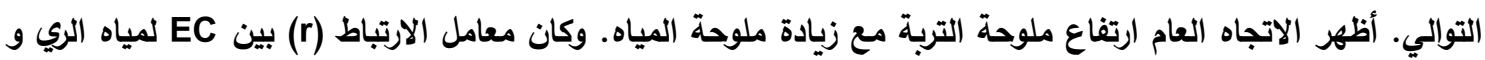
EC 
W. E. Ahmed, et al., 